\title{
Heavy Metals Behavior in Soil/Plant System after Sewage Sludge Application
}

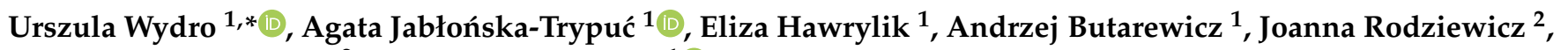 \\ Wojciech Janczukowicz ${ }^{2}$ and Elżbieta Wołejko ${ }^{1}$ (I) \\ 1 Department of Chemistry, Biology and Biotechnology, Faculty of Civil Engineering and Environmental \\ Sciences, Bialystok University of Technology, 15-351 Białystok, Poland; a.jablonska@pb.edu.pl (A.J.-T.); \\ e.hawrylik@pb.edu.pl (E.H.); a.butarewicz@pb.edu.pl (A.B.); e.wolejko@pb.edu.pl (E.W.) \\ 2 Department of Environment Engineering, Faculty of Geoengineering, University of Warmia and Mazury in \\ Olsztyn, Warszawska Street 117a, 10-719 Olsztyn, Poland; joanna.rodziewicz@uwm.edu.pl (J.R.); \\ jawoj@uwm.edu.pl (W.J.) \\ * Correspondence: u.wydro@pb.edu.pl
}

Citation: Wydro, U.;

Jabłońska-Trypuć, A.; Hawrylik, E.;

Butarewicz, A.; Rodziewicz, J.;

Janczukowicz, W.; Wołejko, E. Heavy

Metals Behavior in Soil/Plant System after Sewage Sludge Application. Energies 2021, 14, 1584. https:// doi.org/10.3390/en14061584

Academic Editors: Giovanni Esposito and Attilio Converti

Received: 29 January 2021

Accepted: 10 March 2021

Published: 12 March 2021

Publisher's Note: MDPI stays neutral with regard to jurisdictional claims in published maps and institutional affiliations.

Copyright: (c) 2021 by the authors. Licensee MDPI, Basel, Switzerland. This article is an open access article distributed under the terms and conditions of the Creative Commons Attribution (CC BY) license (https:// creativecommons.org/licenses/by/ $4.0 /)$.

\begin{abstract}
One of the possibilities of removing heavy metals (HMs) from soil is the use of phytoremediation techniques supported with biosolids, which also allow for their disposal. Therefore, the objective of the research was the determination of the sewage sludge suitability after its application to urban soil in order to increase the phytoremediation efficiency of contaminated soil. A field experiment was established on lawns in Białystok (Poland) in two locations with different traffic. The research plots were fertilized with sludge in doses of $14.5 \mathrm{t} \mathrm{DM} /$ ha and $29 \mathrm{t} \mathrm{DM} / \mathrm{ha}$. A mixture of lawn grasses was sown on the prepared plots. During two years of experiment soil/plant samples were collected, and $\mathrm{pH}$, organic matter, dehydrogenase and catalase activity (soil), the total content of $\mathrm{Cd}, \mathrm{Cr}, \mathrm{Cu}, \mathrm{Mo}, \mathrm{Ni}, \mathrm{Pb}, \mathrm{Zn}$, and $\mathrm{Hg}$ (soil/plant), and their fractions (soil) were determined. The HMs in soil were present mainly in residual and reducible fractions. $\mathrm{Zn}$ had the highest share in acid-soluble fractions (17-45\%). The efficiency of urban soil phytoremediation was determined by the calculation of bioconcentration (BCF) and translocation (TF) factors. The highest values for BCF and TF were obtained for Mo (1.97 and 1.99, respectively). In the presented study, sludge amendment caused an immobilization of heavy metals.
\end{abstract}

Keywords: sewage sludge; HMs; fractions; BCF; TF

\section{Introduction}

Urban soils are an integral part of the urban ecosystem, which directly and indirectly determines the quality of life of its inhabitants. Moreover, more than any other type of soil, they are exposed to pollution, both from point and diffuse sources [1,2]. One of the most important aspects determining the chemical properties of soil and land in urban space is the content of heavy metals (HMs). The presence of HMs in urban soils depends on biotic factors (the level of geochemical background, type of bedrock, size of soil sorption, or climatic conditions) and abiotic factors, which include the location, type of industry, the presence of communication routes, topography, or airflow over a given area [3]. According to Chen et al. [4] and Hong et al. [5], the main source of chemical pollution of urban soils with trace elements is primarily an exposition to pollution from the atmosphere. HMs are introduced into soils from the air in the form of industrial dust, or they are released from vehicles when fuels are burned. HMs present in soil can be taken up by plants through the root system. In the case of their high concentrations in soil, there is a risk of their incorporation in the trophic circulation, which may pose a threat to living organisms, including humans. Moreover, too high concentrations of metals in soil reduces the rate of decomposition of organic matter and disrupts the biogeochemical cycle $[1,6]$. 
The overall content of HMs detected in soils may be an indicator of soil contamination and may inform about a potential threat to the environment. In order to determine the bioavailability, toxicity, ability to move, and accumulation of HMs for plants and other living organisms, it is necessary to conduct a speciation analysis, allowing to obtain information regarding the compound that is connected to the metal [7-9]. HMs form a variety of compounds with different availability in soil. They may occur in soil solution in the form of simple ions or complex compounds, in combination with oxides, carbonates, phosphates, and an organic substance. They may also be incorporated into the crystal lattice of minerals, creating a residual fraction. It should be noted that only some of the metals in soil or sediments are bioavailable. One of the most widely used methodologies regarding the sequential extraction of metals is the procedure proposed by the European Community Bureau of Reference (BCR), in which three fractions are determined-easily soluble in an acidic environment, reducible, and oxidizable fractions [10-12]. In order to determine the fraction of HMs, various analytical methods are used, including atomic absorption spectrometry (AAS), the AAS method with electrothermal atomization on iCE 3400 , or the currently preferred inductively coupled plasma optical emission spectroscopy (ICP-OES). The above-mentioned methods allow the determination of the content of metals such as $\mathrm{Cd}, \mathrm{Cr}, \mathrm{Cu}, \mathrm{Ni}, \mathrm{Pb}$, and $\mathrm{Zn}$ in the sample. Metals, such as $\mathrm{Hg}$ and $\mathrm{Mo}$, show greater difficulties in determination, which results from their low content and the influence of the matrix on the reliability of the result. According to the literature data [13-15], in order to determine the $\mathrm{Hg}$ and Mo fractions, electrothermal atomic absorption spectrometry (ET-AAS), cold vapor atomic absorption spectrometry (CV-AAS), atomic fluorescence spectrometry (AFS), inductively coupled plasma atomic emission spectrometry (ICP-AES), inductively coupled plasma mass spectrometry (ICP-MS), and gas chromatography-mass spectrometry (GC-MS) may be used. In case of the low concentrations of some $\mathrm{HMs}(\mathrm{Hg}$, $\mathrm{Mo}$ ) in the sample and because of the use of multiple reagents in the extraction, which can reduce or increase the $\mathrm{Mo} / \mathrm{Hg}$ signal, very sensitive methods are required to eliminate matrix interference. One of these methods can be quadrupole ICP-MS (ICP-QQQ, ICPMS/MS). The high sensitivity of this apparatus and the possibility of removing spectral interferences were achieved by applying the kinetic energy discrimination (KED) mode [16]. Vegetation, including grass, plays an important role in the purification of soil and urban areas. Its role is primarily removing contamination from soil supporting soil-forming processes, stabilizing soil formations, and protecting against water erosion [17]. The use of plants as a cheap and safe repair strategy in the removal of heavy metals from soil is defined as phytoremediation. Phytoremediation concerns the removal of pollutants with the participation of higher plants through their uptake and accumulation in above-ground and underground organs (phytoextraction) or their retention in the rhizosphere (phytostabilization). Microorganisms inhabiting the rhizosphere zone, whose role is to decompose and immobilize some xenobiotics, have a large share in this process [18]. Phytoremediation in urban areas has been used in two fields: the first is post-industrial, while the second is in the vicinity of communication routes, where the adjacent soil is exposed to pollution, including HMs, the main source of which is transport. In order to effectively conduct phytoextraction, soil must be fertile and rich in nutrients to ensure a sufficiently large increase in plant biomass. In turn, plants used in the phytoremediation process should exhibit the following characteristics: tolerance for high concentrations of HMs, fast growth, high biomass production, and profuse root system [19-21]. The properties of HMs, namely, their solubility, bioavailability, and the ability to migrate to plant shoots, are also important factors in phytoremediation processes [22].

The application of sewage sludge characterized by relatively low HMs concentration to soil seems to be an attractive solution applied in order to recycle organic matter into the environment. Several studies have reported that soil treatment with sewage sludge could improve its properties such as soil's aggregate stability, air-water condition, nitrogen, phosphorus and carbon content, and enzyme activities [20,23,24]. 
Choosing the presented research topic was caused by the emerging scientific reports concerning the need to search for new solutions allowing for safe and efficient use of municipal sewage sludge. A rational solution seems to be the use of sewage sludge as a substrate for soil reclamation for lawns along the main communication routes in urbanized areas. Enrichment of soil substrate with sewage sludge supporting phytoremediation conducted with the participation of lawn grass mixtures may allow the urban green zones to be kept in proper appearance and in an appropriate sanitary condition.

Considering the above, the aim of this study was to analyze the influence of sewage sludge application to urban soil on the behavior of heavy metals in soil and plant systems. It was estimated through (1) the analysis of total HMs content and their fractions in soil, (2) the study of HMs level in root and shoot of the lawn grasses, and (3) the calculation of TF and BCF factors. Moreover, the relation between selected properties of soil treated with sewage sludge and the ability of grasses to the uptake of analyzed heavy metals was determined.

\section{Materials and Methods}

\subsection{Study Area}

The study area consisted of plots selected on lawns along communication routes in Białystok (Poland) (Figure 1). The first research object (L1) was marked on the lawn in the lane separating single-lane roadways in the south-western part of the city, and the border of the research objects was located $1 \mathrm{~m}$ and $1.5 \mathrm{~m}$ away from the edge of the road. The average traffic volume was 1157 vehicles per hour. The second research object (L2) was located in the lane separating the two-lane roadways in the western part of the city, and the border of the research objects was located $3-5 \mathrm{~m}$ and $15 \mathrm{~m}$ away from the edge of the road. The average traffic volume for this communication was 2561 vehicles per hour.

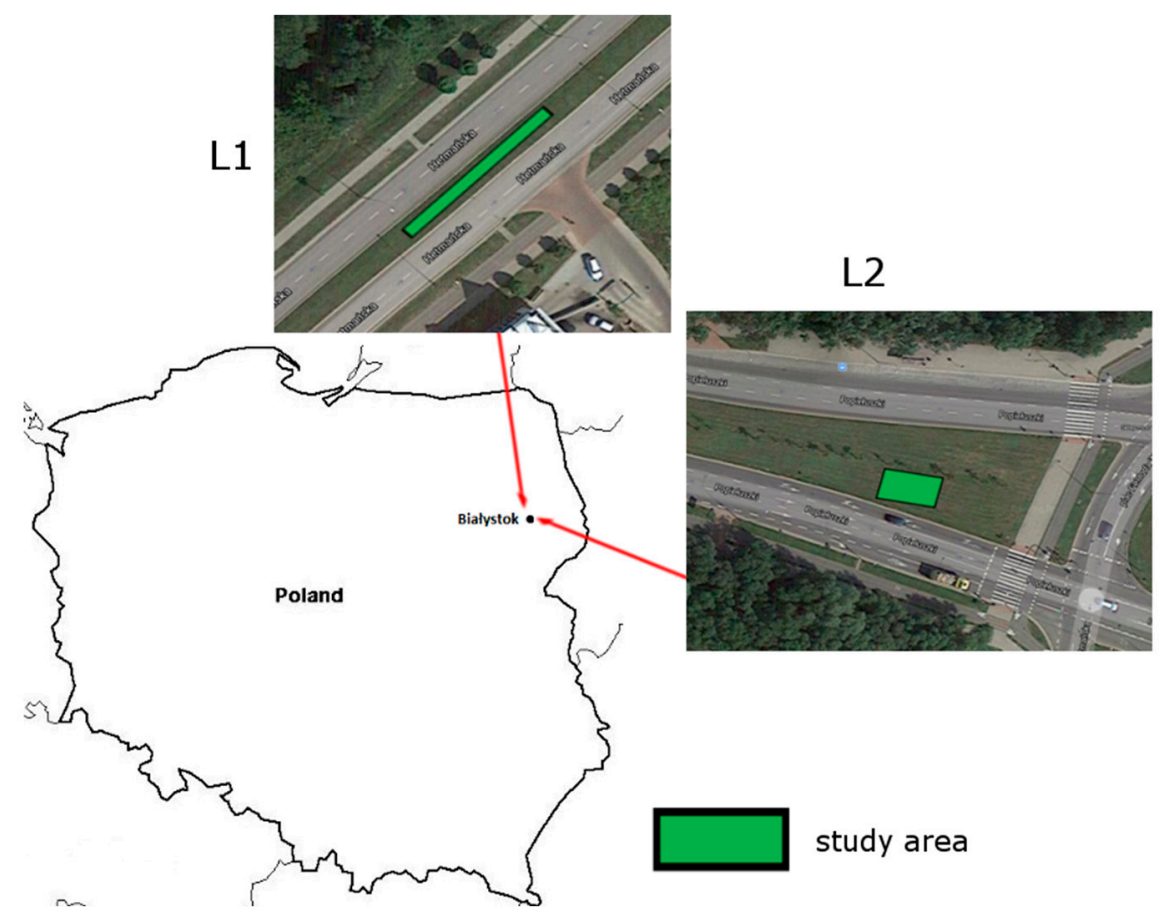

Figure 1. The position of the study area situated in Białystok city in the northeast part of Poland. L1 and L2 are the localizations of the study area along communication routes.

\subsection{Sewage Sludge}

Stabilized sewage sludge in granulated form $(\mathrm{G})$ obtained from the Wastewater Treatment Plant in Białystok ( $\left.53^{\circ} 10^{\prime} 12^{\prime \prime} \mathrm{N}, 23^{\circ} 5^{\prime} 19^{\prime \prime} \mathrm{E}\right)$, was used in order to enrich the soil. Analyzed sewage sludge, after the drainage process on presses, was subjected to thermal 
treatment in a dryer-granular (Keppel Seghers, Willebroek, Belgium), in which the drying temperature reaches $200^{\circ} \mathrm{C}$.

\subsection{Soil and Sewage Sludge Sample Collection before Experiment}

Soil samples (10) were collected from all experimental designated areas $\left(45 \mathrm{~m}^{2}\right)$ from a depth of $0-25 \mathrm{~cm}$. Then, all samples were combined and mixed. Three representative samples were used for the analyzes.

In the example of sewage sludge, 10 samples were collected that were then combined and thoroughly mixed. Three representative samples were used for investigation. The main properties of sewage sludge used in the experiment and soil before starting the experiment in both locations are presented in Table 1.

Table 1. Properties of soil on L1 and L2 and sewage sludge used in the experiment.

\begin{tabular}{|c|c|c|c|c|c|}
\hline Characteristics & L1 & L2 & G & $\begin{array}{l}\text { Detection Limit } \\
{[\mathrm{mg} / \mathrm{kg}]}\end{array}$ & $\begin{array}{c}\text { Relative } \\
\text { Error } \\
{[\%]}\end{array}$ \\
\hline $\mathrm{pH}$ & 8.1 & 7.7 & 8.2 & - & - \\
\hline dry matter (DM), \% & - & - & 81.7 & - & - \\
\hline $\mathrm{OM}, \%$ & - & - & 56.9 & - & - \\
\hline Sand, $\%$ & $76 \pm 5$ & $75 \pm 0.4$ & - & - & - \\
\hline Silt, \% & $22 \pm 2$ & $22 \pm 2$ & - & - & - \\
\hline Clay, \% & $2 \pm 0.1$ & $2 \pm 0.1$ & - & - & - \\
\hline $\mathrm{Cd}, \mathrm{mg} / \mathrm{kg} \mathrm{DM}$ & $0.5 \pm 0.05$ & $0.6 \pm 0.03$ & $1.3 \pm 0.03$ & 0.007 & 1.12 \\
\hline $\mathrm{Cr}, \mathrm{mg} / \mathrm{kg} \mathrm{DM}$ & $12.1 \pm 1.1$ & $11.5 \pm 1.0$ & $76.6 \pm 8.9$ & 0.007 & 1.53 \\
\hline $\mathrm{Cu}, \mathrm{mg} / \mathrm{kg} \mathrm{DM}$ & $16.7 \pm 1.7$ & $26.3 \pm 1.8$ & $198 \pm 26.8$ & 0.003 & 1.22 \\
\hline $\mathrm{Ni}, \mathrm{mg} / \mathrm{kg} \mathrm{DM}$ & $6.3 \pm 0.5$ & $8.5 \pm 0.7$ & $30.1 \pm 4.9$ & 0.02 & 2.04 \\
\hline $\mathrm{Pb}, \mathrm{mg} / \mathrm{kg} \mathrm{DM}$ & $7.5 \pm 0.5$ & $5.6 \pm 0.5$ & $26.0 \pm 3.1$ & 0.007 & 1.18 \\
\hline $\mathrm{Zn}, \mathrm{mg} / \mathrm{kg} \mathrm{DM}$ & $50.8 \pm 4.1$ & $74.4 \pm 4.4$ & $1045 \pm 217$ & 0.01 & 1.96 \\
\hline $\mathrm{Hg}, \mathrm{mg} / \mathrm{kg} \mathrm{DM}$ & $0.04 \pm 0.003$ & $0.19 \pm 0.008$ & $0.95 \pm 0.05$ & 0.00005 & 2.17 \\
\hline
\end{tabular}

The soil and sewage sludge analyses were performed according to the Regulation of the Minister of the Environment of 6 February 2015 on municipal sewage sludge [25]. Reference materials were used in order to control the quality of extraction and determination of heavy metals in soil (NCS DC 73023, soil, LGC Standards, Kiełpin, Poland) and sewage sludge (SRM 2781, domestic sludge, LGC Standards, Kiełpin, Poland).

\subsection{Experiment Design}

The experiment established in each location had an area of $45 \mathrm{~m}^{2}$, which was divided into nine plots of $5 \mathrm{~m}^{2}$ each. In this manner, three blocks (replicates) were obtained, each containing three test plots. In autumn 2015, the soil of test plots was fertilized with sewage sludge $(\mathrm{G})$ in doses of $14.5 \mathrm{t} \mathrm{DM} / \mathrm{ha}(\mathrm{G} 1)$ and $29 \mathrm{t} \mathrm{DM} / \mathrm{ha}(\mathrm{G} 2)$. The control (C) was plot untreated with sewage sludge. In spring 2016, on the prepared plots, the mixture of lawn grass, which included Lolium perenne, Poa pratensis, and Festuca rubra, was seeded. The experiment lasted 24 months.

\subsection{Soil Sampling and Analyses after Sewage Sludge Application}

The soil samples were collected monthly from 6 to 12 months after sewage sludge application in the first year of study (T1), and from 18 to 24 months after sewage sludge application (in the second year-T2). Soil samples were taken from each plot from a depth of $0-25 \mathrm{~cm}$. From each plot, five samples were taken diagonally and placed in a specially described container. Samples from plots with the same study variants were mixed, and then three representative samples were taken for analysis. The samples were brought to the Department of Chemistry, Biology, and Biotechnology (Białystok University of Technology, Białystok, Poland) laboratory; subsequently, they were dried in order to obtain air dry mass 
and sieved through a sieve with a mesh diameter of $2 \mathrm{~mm}$. The samples prepared in this manner were intended at $4^{\circ} \mathrm{C}$ for further analysis.

Soil $\mathrm{pH}$ was measure using a pH-meter (Mettler-Toledo, Polaris Parkway Columbus, $\mathrm{OH}, \mathrm{USA})$ in a suspension containing soil and distilled water with a ratio of 1:2.5 (m:v) [26] Organic matter (OM) was evaluated after the combustion of the sample at $550{ }^{\circ} \mathrm{C}$ in a muffle furnace (LAC, s.r.o., Židlochovice, Czech Republic) and was expressed as losses in weight after ignition [27]. The content of clay (particles less than $0.002 \mathrm{~mm}$ ) was determined by used laser particle size analyzer Analysette 22 NanoTec plus (Fritsch GmbH, Weimar, Germany) according to the manufacturer's instructions. Dehydrogenase activity (DHA) was evaluated by using the colorimetric method according to the procedure proposed by Casida et al. [28] at $\lambda=485 \mathrm{~nm}$ using Lambda Bio+ spectrophotometer (PerkinElmer, Boston, MA, USA). The results were conveyed as micromole of triphenylformazane (TPF) produced by $1 \mathrm{~g}$ of soil dry matter within $20 \mathrm{~h}$ ( $\mu$ mol TPF/(g DM $20 \mathrm{~h}$ ). Catalase activity (CAT) was analyzed by the manganometric assay described by Johnson and Temple [29]. The enzyme activity is expressed as the amount of degraded substrate $\left(\mathrm{H}_{2} \mathrm{O}_{2}\right)$ per minute per $1 \mathrm{~g}$ of dry matter soil ( $\left.\mathrm{mmol} \mathrm{H}_{2} \mathrm{O}_{2} /(\mathrm{g} \mathrm{DM} \mathrm{min})\right)$.

\subsection{Total HMs Content and Their Fractions Levels in Soil}

Soil samples ( $0.5 \mathrm{~g}$ ) were analyzed for $\mathrm{Cd}, \mathrm{Cr}, \mathrm{Cu}, \mathrm{Ni}, \mathrm{Pb}$, and $\mathrm{Zn}$ total content using atomic absorption spectrometry (AAS) method by iCE 3000 Series apparatus (Thermo Scientific, Waltham, MA, USA), while Mo and Hg using Agilent 8800 ICP-MS Triple Quad (ICP-QQQ) System (Agilent Technologies Inc., Santa Clara, CA, USA) after mineralization with aqua regia $\left(\mathrm{HCl}\right.$ and $\mathrm{HNO}_{3}$ in a ratio of 3:1, $\left.9 \mathrm{~mL}: 3 \mathrm{~mL}\right)$ using Advanced Microwave Digestion System Ethos Easy (Milestone, Sorisole (BG), Italy). The conditions of the digestion process were as follows: Step 1: $10 \mathrm{~min}, 200{ }^{\circ} \mathrm{C}, 800 \mathrm{~W}$; Step 2: $15 \mathrm{~min}, 200{ }^{\circ} \mathrm{C}, 800 \mathrm{~W}$. The quality control of HMs extraction and determination in soil was performed using the certified reference material NCS DC 73023 (soil, LGC Standards, Poland). The soil metal fractionation was determined using by BCR sequential extraction method with modification $[30,31]$. It was determined ion exchange and soluble fraction (acid-soluble fraction) (F1), fraction related to iron and manganese oxides-reducible fraction (F2), and oxidizable fraction, associated with organic matter (F3). The residual fraction (F4) was evaluated as the difference between the total metal and the F1, F2, and F3 content. The content of Zn, $\mathrm{Cu}$, and $\mathrm{Pb}$ fractions was measured using the iCE 3000 Series Apparatus (Thermo Scientific, Waltham, MA, USA), while $\mathrm{Cr}, \mathrm{Cd}$, and Ni fractions were determined by the AAS method with electrothermal atomization on the iCE 3400 Apparatus (Thermo Scientific, USA). The content of Mo and Hg fractions was determined by using Agilent 8800 ICP-MS Triple Quad (ICP-QQQ) System (Agilent Technologies Inc., Santa Clara, CA, USA) The quality control of sequential extraction was performed using the certified reference materials, namely, Cd, Cr, Cu, Ni, Pb, and Zn-CRM BCR-701 (sediment, LGC Standards, Poland), $\mathrm{Hg}$-CRM BCR-143R (sewage sludge amended soil, LGC Standards, Kiełpin, Poland) and Mo-CRM-029 (sewage sludge, LGC Standards, Kiełpin, Poland).

\subsection{The Analysis of Lawn Grasses Mixture}

The mixture of grass (root and shoot) was harvested monthly from 6 to 12 months after sewage sludge application in the first year of study (T1), and from 18 to 24 months after sewage sludge application (in the second year of study-T2). The dry matter of the above-ground lawn grass mixture was determined according to $\mathrm{Wu}$ et al. [21]. The results were expressed as the total yield from each study year ( $\mathrm{DM} / \mathrm{ha}$ ). The shoot and root samples intended for $\mathrm{HMs}$ analysis were dried at $60^{\circ} \mathrm{C}$ and ground to a fine powder. Extraction of $\mathrm{Cd}, \mathrm{Cr}, \mathrm{Cu}, \mathrm{Ni}, \mathrm{Pb}$, and $\mathrm{Zn}$ in grass mixture samples $(0.5 \mathrm{~g})$ was performed by digestion in $65 \% \mathrm{HNO}_{3}(7 \mathrm{~mL})$ with $30 \% \mathrm{H}_{2} \mathrm{O}_{2}(2 \mathrm{~mL})$ using Advanced Microwave Digestion System Ethos Easy (Milestone, Italy). The conditions of the digestion process were as follows: Step 1: $4 \mathrm{~min}, 85^{\circ} \mathrm{C}, 800 \mathrm{~W}$; Step 2: $9 \mathrm{~min}, 145^{\circ} \mathrm{C}, 800 \mathrm{~W}$; Step 3: $4 \mathrm{~min}$, $200{ }^{\circ} \mathrm{C}, 800 \mathrm{~W}$; Step 4: $14 \mathrm{~min}, 200{ }^{\circ} \mathrm{C}, 800 \mathrm{~W}$. The content of the heavy metals $(\mathrm{Cd}, \mathrm{Cr}$, 
$\mathrm{Cu}, \mathrm{Ni}, \mathrm{Pb}, \mathrm{Zn}$ ) was evaluated by using the AAS method, and for Mo and $\mathrm{Hg}$, Agilent 8800 ICP-MS Triple Quad (ICP-QQQ) System (Agilent Technologies Inc., USA). The quality control of HMs extraction and determination in grasses was performed using the certified reference material CRM ERM-CD281 (ryegrass, LGC Standards, Kiełpin, Poland).

\subsection{Bioaccumulation (BCF) and Translocation (TF) Factors Evaluation}

The bioconcentration factor of metal (BCF) was calculated as the quotient of the content of the metal in the above-ground part of the grass mixture $(\mathrm{mg} / \mathrm{kg} \mathrm{DM})$ and the total heavy metal content in soil ( $\mathrm{mg} / \mathrm{kg} \mathrm{DM})$. Translocation factor (TF) was determined as a ratio of heavy metal content in the shoot $(\mathrm{mg} / \mathrm{kg} \mathrm{DM})$ to heavy metal content in the root (mg/kg DM).

\subsection{Statistical Analysis}

The statistical analysis was performed using Statistica 13.1 software (StatSoft Poland, Cracow, Poland). The obtained data were presented as mean \pm standard deviation (SD) of triplicate. The multiple variances of ANOVA (MANOVA) were used to evaluate differences between various treatments, locations, and time of sampling. The significant differences were assessed by the Tukey test at $p<0.05$. The relationships between examined parameters were explained by Pearson's correlation analysis at $p<0.05$.

\section{Results}

\subsection{Soil Properties after Sewage Sludge Application}

The selected properties of soil are shown in Table 2. Both at L1 and L2, different values of soil $\mathrm{pH}$ measured in water within the range of neutral and alkaline reaction were observed. In T1, soil pH ranged from 7.05 to 7.48. Similar values were also recorded in T2 (from 6.96 to 7.65 ), with the clay content in soil from $5 \%$ to $6 \%$.

Table 2. Selected properties of soil samples from control plots $(C)$ and treated with sewage sludge in a dose of $14.5 \mathrm{t} D M /$ ha (G1) and 29 t DM/ha (G2) in L1 and L2, collected in first (T1) and second (T2) year of study.

\begin{tabular}{|c|c|c|c|c|c|c|}
\hline Location & Term & Treatment & $\underset{\text { Min-Max }}{\mathrm{pH}}$ & $\begin{array}{c}\text { OM } \\
\text { (\% DM) }\end{array}$ & $\begin{array}{c}\text { DHA } \\
(\mu \mathrm{mol} \mathrm{TPF} / \mathrm{g} \\
\mathrm{DM} / 20 \mathrm{~h})\end{array}$ & $\begin{array}{c}\text { CAT } \\
\underset{\left(\mathrm{mmol} \mathrm{H} \mathrm{H}_{2} \mathrm{O}_{2} / \mathrm{g}\right.}{\mathrm{DM} / \mathrm{min})}\end{array}$ \\
\hline \multirow{6}{*}{ L1 } & \multirow{3}{*}{$\mathrm{T} 1$} & $\mathrm{C}$ & $7.27-7.45$ & $4.44 \pm 0.46$ & $0.22 \pm 0.08$ & $7.59 \pm 1.28$ \\
\hline & & G1 & $7.26-7.37$ & $6.38 \pm 0.42$ & $0.30 \pm 0.16$ & $8.75 \pm 0.56$ \\
\hline & & G2 & $7.05-7.37$ & $8.27 \pm 2.19$ & $0.32 \pm 0.17$ & $8.33 \pm 1.39$ \\
\hline & \multirow{3}{*}{$\mathrm{T} 2$} & $\mathrm{C}$ & $7.08-7.55$ & $5.12 \pm 1.09$ & $0.46 \pm 0.32$ & $7.82 \pm 1.57$ \\
\hline & & G1 & $6.97-7.29$ & $7.59 \pm 2.06$ & $0.53 \pm 0.09$ & $9.60 \pm 1.57$ \\
\hline & & G2 & $6.96-7.25$ & $8.21 \pm 0.90$ & $0.60 \pm 0.25$ & $9.77 \pm 3.85$ \\
\hline \multirow{6}{*}{ L2 } & \multirow{3}{*}{$\mathrm{T} 1$} & $C$ & $7.10-7.34$ & $6.11 \pm 0.65$ & $0.22 \pm 0.03$ & $7.86 \pm 0.43$ \\
\hline & & G1 & $7.18-7.48$ & $6.47 \pm 0.92$ & $0.30 \pm 0.08$ & $8.87 \pm 0.32$ \\
\hline & & G2 & $7.23-7.41$ & $7.90 \pm 0.69$ & $0.34 \pm 0.08$ & $9.55 \pm 0.70$ \\
\hline & \multirow{3}{*}{$\mathrm{T} 2$} & $\mathrm{C}$ & $7.00-7.65$ & $5.99 \pm 0.62$ & $0.28 \pm 0.17$ & $8.48 \pm 1.30$ \\
\hline & & G1 & $7.05-7.64$ & $6.28 \pm 0.66$ & $0.38 \pm 0.17$ & $8.64 \pm 1.17$ \\
\hline & & G2 & $6.99-7.46$ & $7.96 \pm 0.73$ & $0.42 \pm 0.12$ & $8.97 \pm 0.59$ \\
\hline
\end{tabular}

In $\mathrm{T} 1$ and $\mathrm{T} 2$, at locations $\mathrm{L} 1$ and $\mathrm{L} 2$, the content of $\mathrm{OM}$ in soil from each study site was at similar levels. In T1, soil OM content was lowest in C in L1 (4.44\% DM), while it was highest in soil with a double dose of dried sludge in L1 (8.27\% DM). In T2, soil OM content was similar to that from $\mathrm{T} 1$ ranging from $5.12 \%(\mathrm{C}, \mathrm{L} 1)$ to $8.21 \% \mathrm{DM}(\mathrm{G} 2, \mathrm{~L} 1)$. OM content did not differ significantly depending on the sludge dose applied.

As presented in Table 2, in T1, the activity of DHA was from $0.22 \mu \mathrm{mol} \mathrm{TPF} /(\mathrm{g}$ DM $20 \mathrm{~h}$ ) to $0.60 \mu \mathrm{mol} \mathrm{TPF} /(\mathrm{g} \mathrm{DM} 20 \mathrm{~h})$, and higher values were obtained for the samples collected from the plots with G. In T2, the range of activities of DHA was from $0.28 \mu \mathrm{mol}$ $\mathrm{TPF} /(\mathrm{g} \mathrm{DM} 20 \mathrm{~h}$ ) to $0.60 \mu \mathrm{mol} \mathrm{TPF} /(\mathrm{g} \mathrm{DM} 20 \mathrm{~h}$ ), for C in L2 and G2 in L1, respectively. 
The activity of CAT in the soil in T1 was from $7.59 \mu \mathrm{mol} \mathrm{H}_{2} \mathrm{O}_{2} /(\mathrm{g}$ DM min) (C, L1) to $9.55 \mu \mathrm{mol} \mathrm{H} \mathrm{O}_{2} /$ (g DM min) (G2, L2). In T2, the range of CAT activity in the soil for the analyzed objects was from $7.82 \mu \mathrm{mol} \mathrm{H}_{2} \mathrm{O}_{2} /\left(\mathrm{g}\right.$ DM min) (C, L1) to $9.77 \mu \mathrm{mol} \mathrm{H}_{2} \mathrm{O}_{2} /(\mathrm{g} \mathrm{DM}$ $\mathrm{min}),(\mathrm{G} 2, \mathrm{~L} 1)$. Generally, CAT activity was higher in the soil amended with $\mathrm{G}$ as compared to $C$. The application of $\mathrm{G}$ to the soil at L2 in T1 caused a significant increase in CAT activity with the $G$ dose.

\subsection{Heavy Metals and Their Fractions Concentration in Soil}

Figure 2 presents the total content of $\mathrm{Cd}, \mathrm{Cr}, \mathrm{Cu}, \mathrm{Mo}, \mathrm{Ni}, \mathrm{Pb}, \mathrm{Zn}$, and $\mathrm{Hg}$ in the soil in T1 and T2, while Figure 3 depicts the share of F1, F2, F3, and F4 fractions in the total content of the tested HMs.
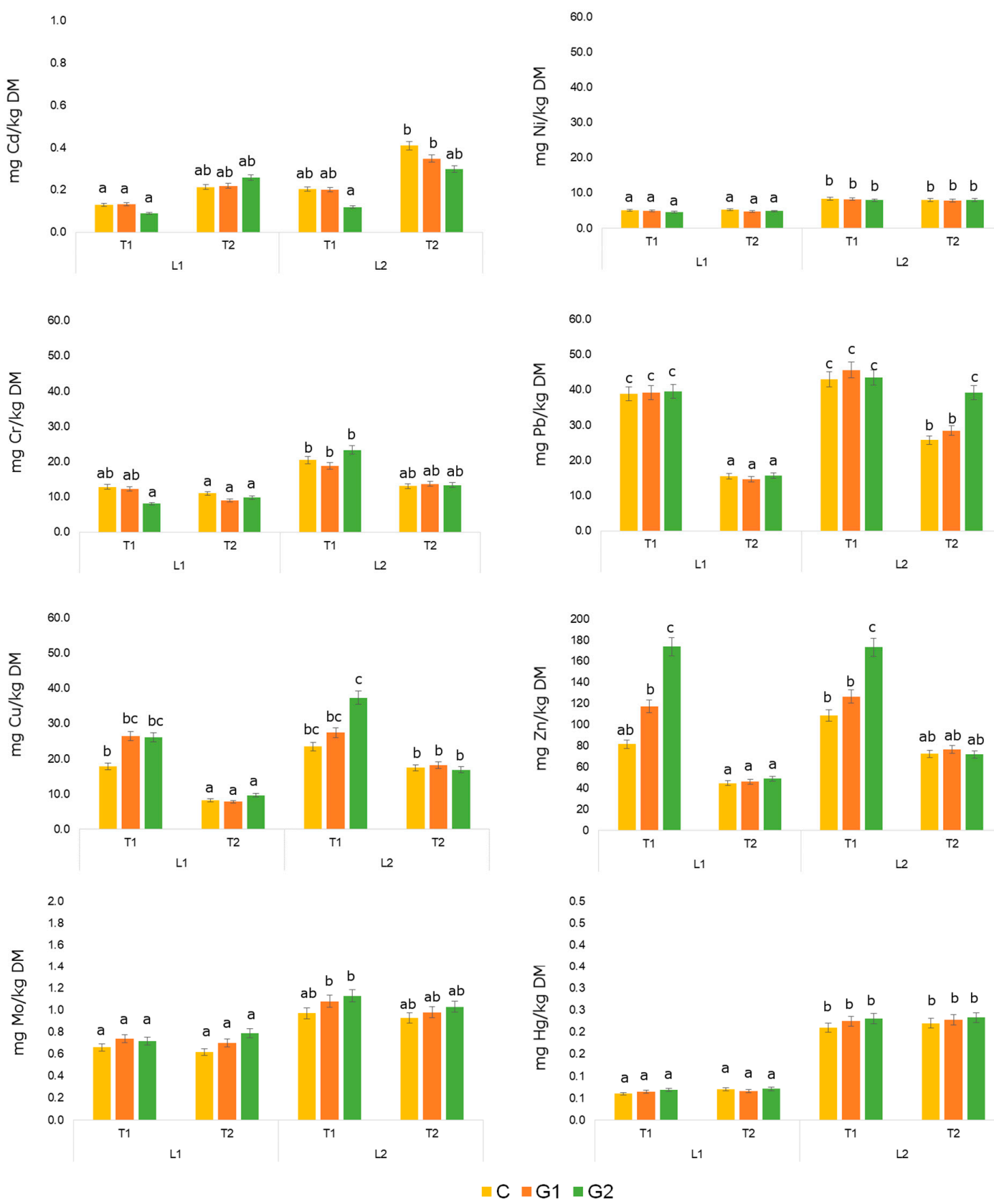

Figure 2. The average content of total heavy metals $(\mathrm{HMs})(\mathrm{Cd}, \mathrm{Cr}, \mathrm{Cu}, \mathrm{Mo}, \mathrm{Ni}, \mathrm{Pb}, \mathrm{Zn}$, and $\mathrm{Hg})$ in soil samples from the control plots (C) and plots fertilized with sewage sludge in a dose of $14.5 \mathrm{t} \mathrm{DM} / \mathrm{ha}$ (G1) and $29 \mathrm{t} \mathrm{DM} / \mathrm{ha}$ (G2) in L1 and L2, collected in the first (T1) and second (T2) year of study. Different letters above bars (mean \pm SD) represent significant differences assessed with the Tukey test at $p<0.05$. 
$\mathrm{Cd}$

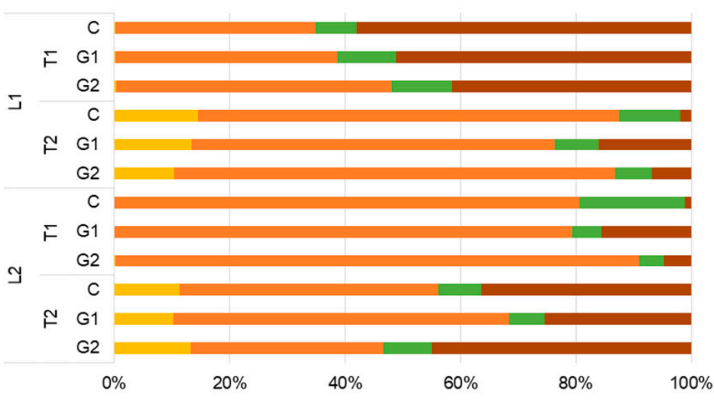

$\mathrm{Cr}$

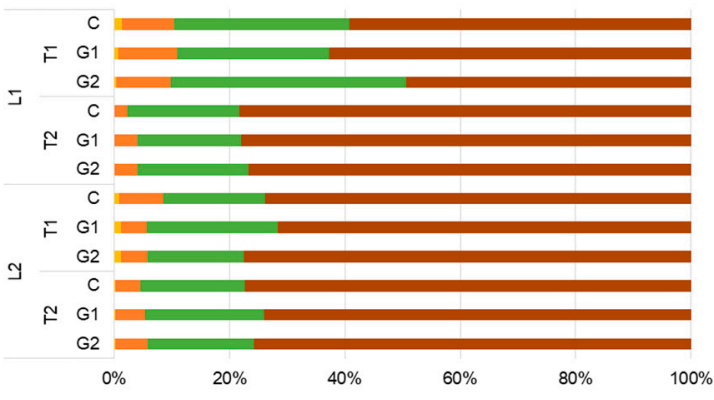

Cu

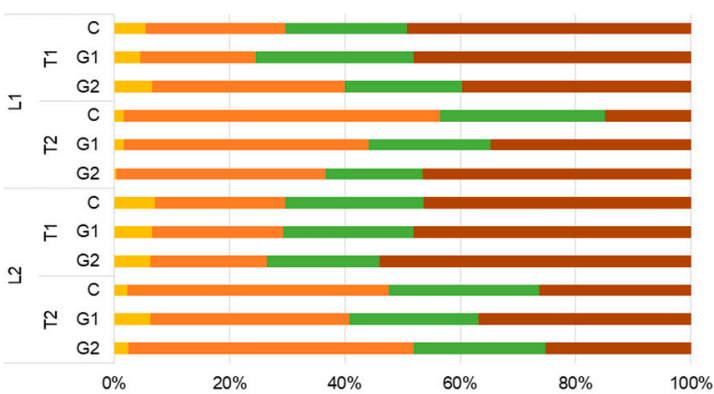

Mo

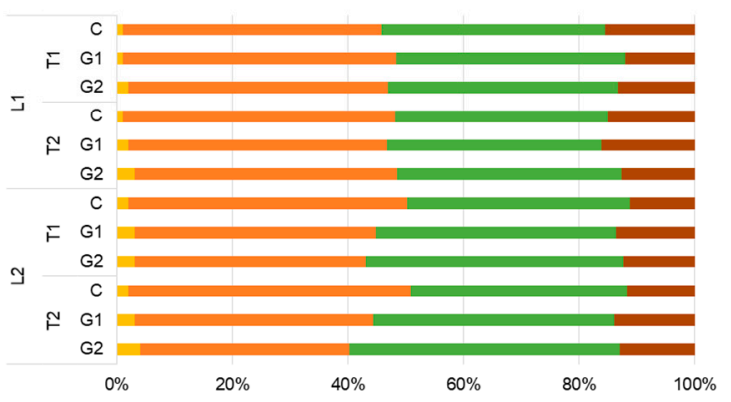

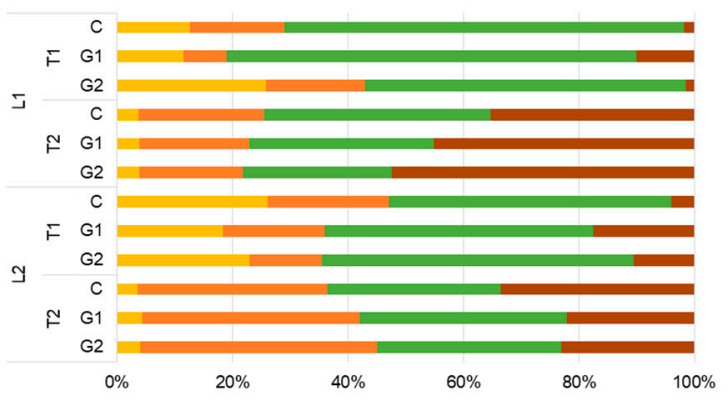

$\mathrm{Pb}$

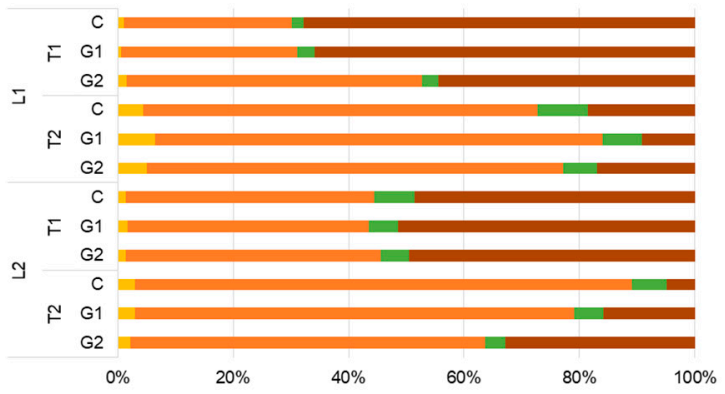

$\mathrm{Zn}$

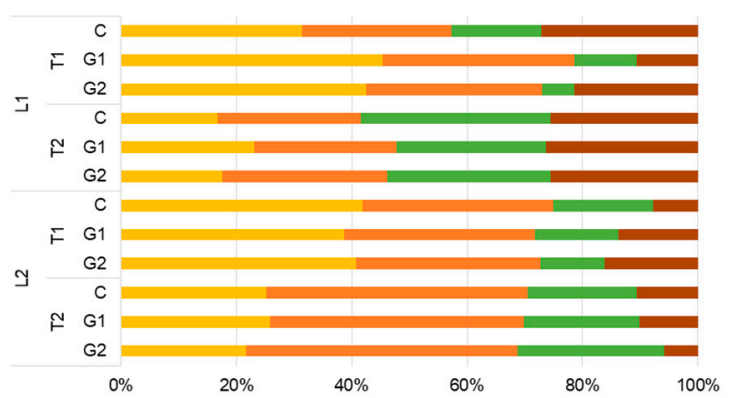

$\mathrm{Hg}$

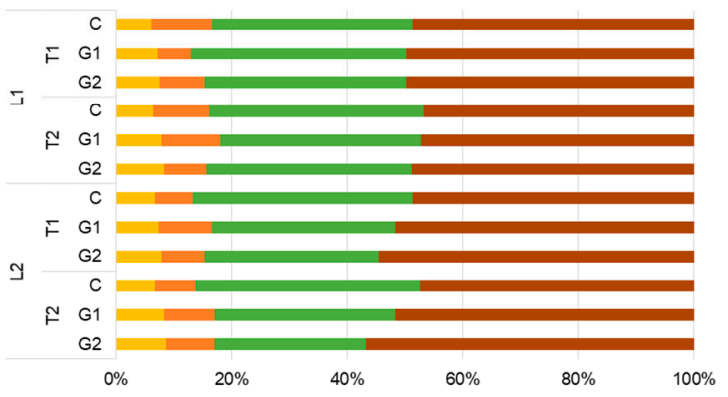

$\mathrm{F} 1-\mathrm{F} 2 \square \mathrm{F} 3-\mathrm{F} 4$

Figure 3. The share of the acid-soluble fraction (F1), fraction related to iron and manganese oxides-reducible fraction (F2), the oxidizable fraction (F3), and the residual fraction (F4) in the total content of $\mathrm{Cd}, \mathrm{Cr}, \mathrm{Cu}, \mathrm{Mo}, \mathrm{Ni}, \mathrm{Pb}, \mathrm{Zn}$, and $\mathrm{Hg}$ in soil samples from the control plots (C) and plots fertilized with sewage sludge in a dose of $14.5 \mathrm{t} \mathrm{DM} / \mathrm{ha}(\mathrm{G} 1)$ and $29 \mathrm{t} \mathrm{DM} / \mathrm{ha}$ (G2) in L1 and L2, collected in the first (T1) and second (T2) year of study.

In $\mathrm{T} 1$, the average $\mathrm{Cd}$ content in soil was from $0.09 \mathrm{mg} / \mathrm{kg} \mathrm{DM}$ to $0.20 \mathrm{mg} / \mathrm{kg} \mathrm{DM}$, while in T2, it increased to the values from $0.21 \mathrm{mg} / \mathrm{kg} \mathrm{DM}$ to $0.41 \mathrm{mg} / \mathrm{kg}$ DM. It was 
found that the average cadmium content in the soil in L2 differed significantly in T1 and T2. In $\mathrm{T} 1$, most $\mathrm{Cd}$ was present in the $\mathrm{F} 2$ and $\mathrm{F} 4$ fractions, and its share ranged from $35 \%$ to $91 \%$ and from $1 \%$ to $59 \%$, respectively. The share in the F3 fraction ranged from $4 \%$ to $18 \%$ and in the F1 fraction reached the value $<1 \%$. In T2, as compared with the T1, the share of $\mathrm{Cd}$ in the F2 decreased to the values from $33 \%$ to $76 \%$ and the share of $\mathrm{F} 1$ increased (10-14\%). The share of Cd in the F4 fraction ranged from $2 \%$ to $45 \%$, while that in the F3 fraction ranged from $6 \%$ to $11 \%$. The application of sewage sludge to soil did not cause any significant differences in the share of $\mathrm{Cd}$ in the analyzed fractions.

In $\mathrm{T} 1$, the average total $\mathrm{Cr}$ content in soils had different values that ranged from $8.1 \mathrm{mg} / \mathrm{kg}$ DM (G2, L1) to $23.3 \mathrm{mg} / \mathrm{kg}$ DM (G2, L2). In T2, the total content of this metal in soil samples was lower than in T1 and ranged from $9.0 \mathrm{mg} / \mathrm{kg}$ DM to $13.7 \mathrm{mg} / \mathrm{kg}$ DM for G1, L1, and G1, L2, respectively. The analysis of variance of the results showed that the average content of total $\mathrm{Cr}$ in soil samples from the $\mathrm{C}$ and G2 in L2 was significantly lower than in G2, L2. The highest percent of Cr in T1 and T2 was associated with F4 (49-78\%), followed by F3 fraction (17-41\%). The share of the F2 fraction was from $2 \%$ to $10 \%$, while $\mathrm{F} 1$ exceeded 1\%. In T2, in the samples from L1, the share of Cr in F2 and F3 decreased as compared to that from $\mathrm{T} 1$, while the percentage of $\mathrm{Cr}$ in the $\mathrm{F} 4$ fraction increased.

The average $\mathrm{Cu}$ content in the soil in T1 was $17.9-37.4 \mathrm{mg} / \mathrm{kg}$ DM. In T2, the average $\mathrm{Cu}$ content in soil decreased significantly and in $\mathrm{L} 1$ ranged from $7.9 \mathrm{mg} / \mathrm{kg} \mathrm{DM}$ to $9.7 \mathrm{mg} / \mathrm{kg} \mathrm{DM}$, while in L2 from $16.9 \mathrm{mg} / \mathrm{kg}$ DM to $18.2 \mathrm{mg} / \mathrm{kg}$ DM. Moreover, in T1, the concentration of $\mathrm{Cu}$ was higher in soil samples from G1 and G2 at both localization than in those from $C$, but the increase was not statistically significant. In the soil from $C$ and from plots with $\mathrm{G}$, the highest $\mathrm{Cu}$ concentration in T1 was in F4 (from $40 \%$ to $54 \%$ ), in F3 fraction was 20-27\%, and in the F2, 20-33\%, while the share of Cu in F1 fraction was $5-7 \%$. In $\mathrm{T} 2$, the share of $\mathrm{Cu}$ in the F4 fraction decreased (15-46\%), while the share in the F2 fraction increased (35-55\%).

Mo content in the soil in T1 was from $0.66 \mathrm{mg} / \mathrm{kg}$ DM to $1.13 \mathrm{mg} / \mathrm{kg}$ DM. A significantly higher Mo content was observed for samples from L2. In T2, the content of Mo was similar as in T1 and ranged from $0.62 \mathrm{mg} / \mathrm{kg}$ DM to $1.03 \mathrm{mg} / \mathrm{kg}$ DM. We did not observe a significant effect of sewage sludge-amendments on Mo content in the soil. In T1 and T2, most of Mo was bound in F2 (36-48\%) and F3 (37-46\%) fractions. The share of Mo in F1 and F4 were from $1 \%$ to $4 \%$ and from $11 \%$ to $16 \%$, respectively.

Both in $\mathrm{T} 1$ and $\mathrm{T} 2$, the content of $\mathrm{Ni}$ in the soil had similar average values ranging from $4.6 \mathrm{mg} / \mathrm{kg}$ DM to $8.3 \mathrm{mg} / \mathrm{kg}$ DM. Significant differences in Ni content were conducted in the soil sampled from L1 and L2. Significantly higher Ni contents were observed at L2. In T1, most Ni was bound in F3 fraction (40-54\%), followed by F4 fraction (1-18\%), F2 fraction (7-21\%), and F1 fraction (11-26\%). In T2 at L1, there was an increase in the Ni share in the fractions F2 and F4, with a decrease in the Ni share in the F3 and F1 fractions. The $\mathrm{L} 2$ site, on the other hand, showed an increase in $\mathrm{Ni}$ in the $\mathrm{F} 4$ fraction and a decrease in $\mathrm{Ni}$ in the $\mathrm{F} 1$ and $\mathrm{F} 3$ fractions.

It was found that the content of total $\mathrm{Pb}$ in $\mathrm{T} 1$ ranged from $38.8 \mathrm{mg} / \mathrm{kg} \mathrm{DM}$ to $39.6 \mathrm{mg} / \mathrm{kg}$ DM (L1) and from $43.1 \mathrm{mg} / \mathrm{kg}$ DM to $45.7 \mathrm{mg} / \mathrm{kg}$ DM in L2. On the other hand, in T2, the average value of the discussed metal decreased significantly, reaching $14.7-15.7 \mathrm{mg} / \mathrm{kg}$ DM (L1) and 25.7-39.2 mg/ $\mathrm{kg}$ DM (L2). Considering the contribution of individual $\mathrm{Pb}$ fractions in the total content of soil samples, in $\mathrm{T} 1$ most $\mathrm{Pb}$ was presented in the F4 fraction, and its share ranged from $44 \%$ to $68 \%$; in the F2 fraction, Pb bounded from $29 \%$ to $51 \%$, and in the F3 fraction, $2-7 \%$, while in the F1 fraction, $1-2 \%$. In T2, the share of $\mathrm{Pb}$ increased in the $\mathrm{F} 2$ fraction at both locations and ranged from $62 \%$ to $86 \%$, while the share of $\mathrm{Pb}$ decreased in the F4 fraction (5-33\%).

In T1, the Zn content in soil was different and ranged from $81.7 \mathrm{mg} / \mathrm{kg} \mathrm{DM}(\mathrm{C}, \mathrm{L} 1)$ to $173.8 \mathrm{mg} / \mathrm{kg}$ DM. (G1, L1). Moreover, the content of this metal in soil increased significantly with the dose of G. In T2, the content of this metal in soil decreased significantly with the values within the ranges $44.6-48.9 \mathrm{mg} / \mathrm{kg}$ DM (L1) and 71.7-76.4 mg/ $\mathrm{kg}$ DM. (L2). Considering the contribution of $\mathrm{Zn}$ fractions to the total content, in the first year, the greatest 
amount of Zn was observed in the F1 fraction (31-45\%), then in the F2 fraction with 26-33\% $\mathrm{Zn}$, and in the F3 fraction, 6-17\%, while in the F4 fraction, 8-27\%. In T1, the share of $\mathrm{Zn}$ in F2 (25-47\%) and F3 (19-33\%) fractions increased, while it decreased in the F1 fraction $(17-26 \%)$.

In the tested soil, $\mathrm{Hg}$ content at L1 was from $0.06 \mathrm{mg} / \mathrm{kg}$ DM to $0.071 \mathrm{mg} / \mathrm{kg} \mathrm{DM}$. The significantly higher values of $\mathrm{Hg}$ were reported in soil samples from L2 and were from $0.21 \mathrm{mg} / \mathrm{kg}$ DM to $0.23 \mathrm{mg} / \mathrm{kg}$ DM. The sewage sludge-treatment did not significantly influence $\mathrm{Hg}$ content in soil samples. The highest percentage content of $\mathrm{Hg}$ was noted in F4 (47-57\%) and F3 (26-38\%) fractions. The share of Hg in F1 and F2 fractions was approximately $10 \%$.

\subsection{The Total Yield and HMs Content in Grass}

As presented in Figure 4, in T1 and T2, on C at L1 and L2, the total yield was at a similar level of approximately $2.5 \mathrm{t} \mathrm{DM} / \mathrm{ha}$. In T1 of the study, after the application of G1 and G2 at L1, the total yield increased significantly by $76 \%$ and $104 \%$, respectively, compared to C. On the other hand, at L2 after application of G1 and G2, the total yield increased by $63 \%$ and $86 \%$, respectively. In the next year at L1, after the application of G1 and G2, the total yield reached a similar level of approximately $4.8 \mathrm{t} \mathrm{DM} / \mathrm{ha}$, while at L2, there was a significant increase in the total yield by approximately $92 \%$ and $123 \%$, respectively, compared to $C$.

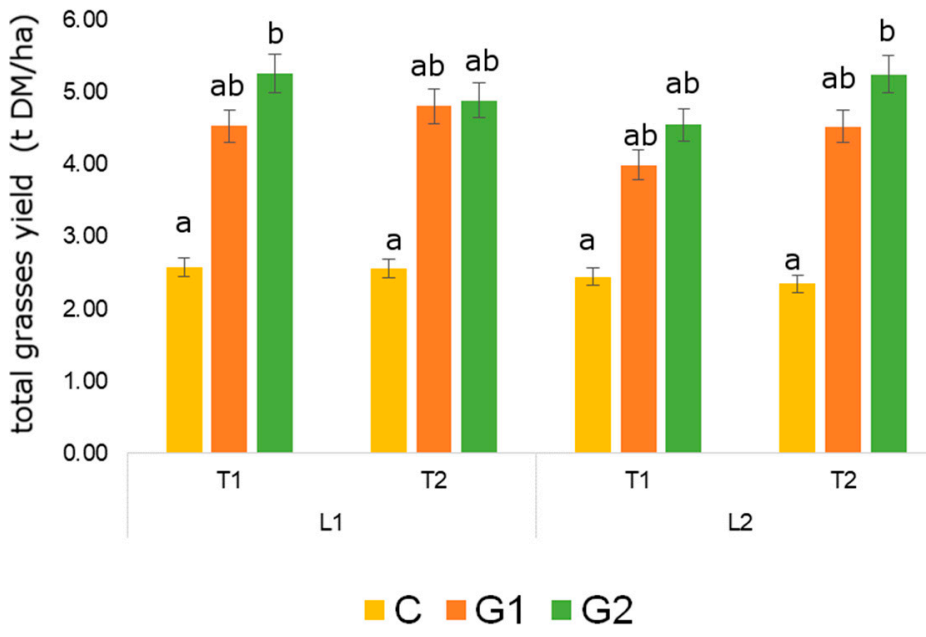

Figure 4. The total shoot yield of grass mixture from the control plots $(\mathrm{C})$ and plots fertilized with sewage sludge in a dose of $14.5 \mathrm{t} \mathrm{DM} / \mathrm{ha}(\mathrm{G} 1)$ and $29 \mathrm{t} \mathrm{DM} / \mathrm{ha}$ (G2) in L1 and L2, collected in first (T1) and second (T2) year of study. The different letter above bars (mean $\pm \mathrm{SD}$ ) represented significant differences assessed with the Tukey test at $p<0.05$.

The average content of $\mathrm{Cd}, \mathrm{Cr}, \mathrm{Cu}, \mathrm{Mo}, \mathrm{Ni}, \mathrm{Pb}, \mathrm{Zn}$, and $\mathrm{Hg}$ in shoots and roots of lawn grass mixture is presented in Figure 5. The concentration of $\mathrm{Cd}$ in shoot samples in T1 was from $0.06 \mathrm{mg} / \mathrm{kg}$ DM to $0.13 \mathrm{mg} / \mathrm{kg}$ DM and higher values were obtained for samples from plots fertilized with sewage sludge. The content of $\mathrm{Cd}$ in the root was from $0.04 \mathrm{mg} / \mathrm{kg}$ DM to $0.11 \mathrm{mg} / \mathrm{kg}$ DM. In T2, the concentration of Cd in the above-ground part of grasses was similar $(0.08-0.15 \mathrm{mg} / \mathrm{kg} \mathrm{DM})$. The greatest value was observed for samples from plots G2 in location L2. The highest content of Cd in roots $(0.11 \mathrm{mg} / \mathrm{kg} \mathrm{DM})$ was observed in samples from G2, L2. Cr concentration in the above-ground part of grass mixture in T1 was from $0.43 \mathrm{mg} / \mathrm{kg} \mathrm{DM}$ to $0.50 \mathrm{mg} / \mathrm{kg} \mathrm{DM}$, while in T2, the concentration of this metal was significantly higher, both L1 and L2, and was from $1.98 \mathrm{mg} / \mathrm{kg}$ DM to $2.46 \mathrm{mg} / \mathrm{kg}$ DM. No significant differences were found in $\mathrm{Cr}$ concentration in plants, depending on the sewage sludge dose applied. Higher contents of $\mathrm{Cr}$ were found in root samples, both in T1 and T2, and were 1.16-2.65 mg/ kg DM and 3.62-11.66 mg/kg DM, respectively. $\mathrm{Cu}$ content in the shoot part of grasses in $\mathrm{T} 1 \mathrm{was}$ from $8.1 \mathrm{mg} / \mathrm{kg} \mathrm{DM}$ to 
$14.4 \mathrm{mg} / \mathrm{kg}$ DM for control, L1, and G2, L2, respectively. In T2, the accumulation of Cu was from $7.8 \mathrm{mg} / \mathrm{kg}$ DM (C, L1) to $13.3 \mathrm{mg} / \mathrm{kg}$ DM (G1, L2). The significant effect of $\mathrm{G}$ treatment was noted in T2 for location L1 and in T2 for L2, where Cu concentration in plant samples from G1 and G2 was higher than control. In root samples, the content of Cu was from $11.34 \mathrm{mg} / \mathrm{kg}$ DM to $20.71 \mathrm{mg} / \mathrm{kg}$ DM (T1) and from $8.95 \mathrm{mg} / \mathrm{kg}$ DM to $19.68 \mathrm{mg} / \mathrm{kg}$ DM (T2). The significantly higher values of $\mathrm{Cu}$ were noticed in root samples from plots sewage sludge amended. Mo uptake by grasses to shoot parts in T1 was from $0.98 \mathrm{mg} / \mathrm{kg}$ DM to $1.89 \mathrm{mg} / \mathrm{kg}$ DM, while in T2 was from $1.05 \mathrm{mg} / \mathrm{kg}$ DM to $1.92 \mathrm{mg} / \mathrm{kg}$ DM. The higher values were noted for shoot samples from plots G1, but obtained results were not statistically significant. The accumulation of Mo in root parts of grasses in T1 was from $0.59 \mathrm{mg} / \mathrm{kg}$ DM to $1.63 \mathrm{mg} / \mathrm{kg}$ DM. In T2, the content of this metal in roots was ranged from $0.58 \mathrm{mg} / \mathrm{kg}$ DM to $1.65 \mathrm{mg} / \mathrm{kg}$ DM. The significant differences between Mo content in shoots and roots for samples from plots amendment with sludge at L2 were indicated. Ni accumulation in grass mixture shoots in T1 was from $1.99 \mathrm{mg} / \mathrm{kg} \mathrm{DM}(\mathrm{C}$, L1) to $2.52 \mathrm{mg} / \mathrm{kg} \mathrm{DM}(\mathrm{G} 2, \mathrm{~L} 2)$. In T2, a significant decrease of Ni concentration in plant was noticed $(0.76-1.15 \mathrm{mg} / \mathrm{kg} \mathrm{DM})$. We did not observe a significant effect of $\mathrm{G}$ dose application to soil on Ni concentration of lawn mixture of grasses. The accumulation of $\mathrm{Ni}$ in roots in T1 was from $2.83 \mathrm{mg} / \mathrm{kg}$ DM to $8.98 \mathrm{mg} / \mathrm{kg}$ DM, whereas in T2 significantly decreased and was from $1.99 \mathrm{mg} / \mathrm{kg}$ DM to $5.61 \mathrm{mg} / \mathrm{kg}$ DM. The concentration of $\mathrm{Pb}$ in the shoot of examined grasses was from $0.71 \mathrm{mg} / \mathrm{kg}$ DM to $0.83 \mathrm{mg} / \mathrm{kg} \mathrm{DM}$ in T1, while in T2 was from $0.83 \mathrm{mg} / \mathrm{kg} \mathrm{DM}$ to $1.47 \mathrm{mg} / \mathrm{kg} \mathrm{DM}$. In root samples, Pb content was similar in T1 and T2 and was from $2.54 \mathrm{mg} / \mathrm{kg}$ DM to $5.18 \mathrm{mg} / \mathrm{kg}$ DM. We noted no significantly different content of $\mathrm{Pb}$ in roots after $\mathrm{G}$ application. The presented data indicate that the concentration of $\mathrm{Zn}$ in the shoot of lawn grasses mixture in $\mathrm{T} 1$ was from $51.6 \mathrm{mg} / \mathrm{kg}$ DM to $71.9 \mathrm{mg} / \mathrm{kg}$ DM and significantly higher values were noted for samples collected from G-treated plots. In T2 of the experiment, Zn concentration in analyzed plants was similar as in T1 (53.7-71.3 mg/kg DM). A significant increase in Zn concentration in plants shoot dependent on sewage sludge dose was observed. A significantly lower accumulation of $\mathrm{Zn}$ in grass roots was noted in T2 (42.4-66.5 mg/ $\mathrm{kg} \mathrm{DM})$, as compared to T1 (59.8-110.1 mg/kg DM). In T1, the effect of sewage sludge treatment was noticed. In T1, $\mathrm{Hg}$ content in the shoot part of grasses was from $1.30 \mu \mathrm{g} / \mathrm{kg}$ DM to $2.50 \mu \mathrm{g} / \mathrm{kg} \mathrm{DM}$, while in T2, from $1.50 \mu \mathrm{g} / \mathrm{kg}$ DM to $2.70 \mu \mathrm{g} / \mathrm{kg}$ DM. Hg uptake by grass roots was higher than by shoots and in T1 was from $1.71 \mu \mathrm{g} / \mathrm{kg}$ DM to $3.03 \mu \mathrm{g} / \mathrm{kg}$ DM. In T2, the content of this metal in roots was ranged from $1.87 \mu \mathrm{g} / \mathrm{kg}$ DM to $3.31 \mu \mathrm{g} / \mathrm{kg}$ DM. The significant effect of sewage sludge treatment on $\mathrm{Hg}$ accumulation in roots and shoots was observed. 

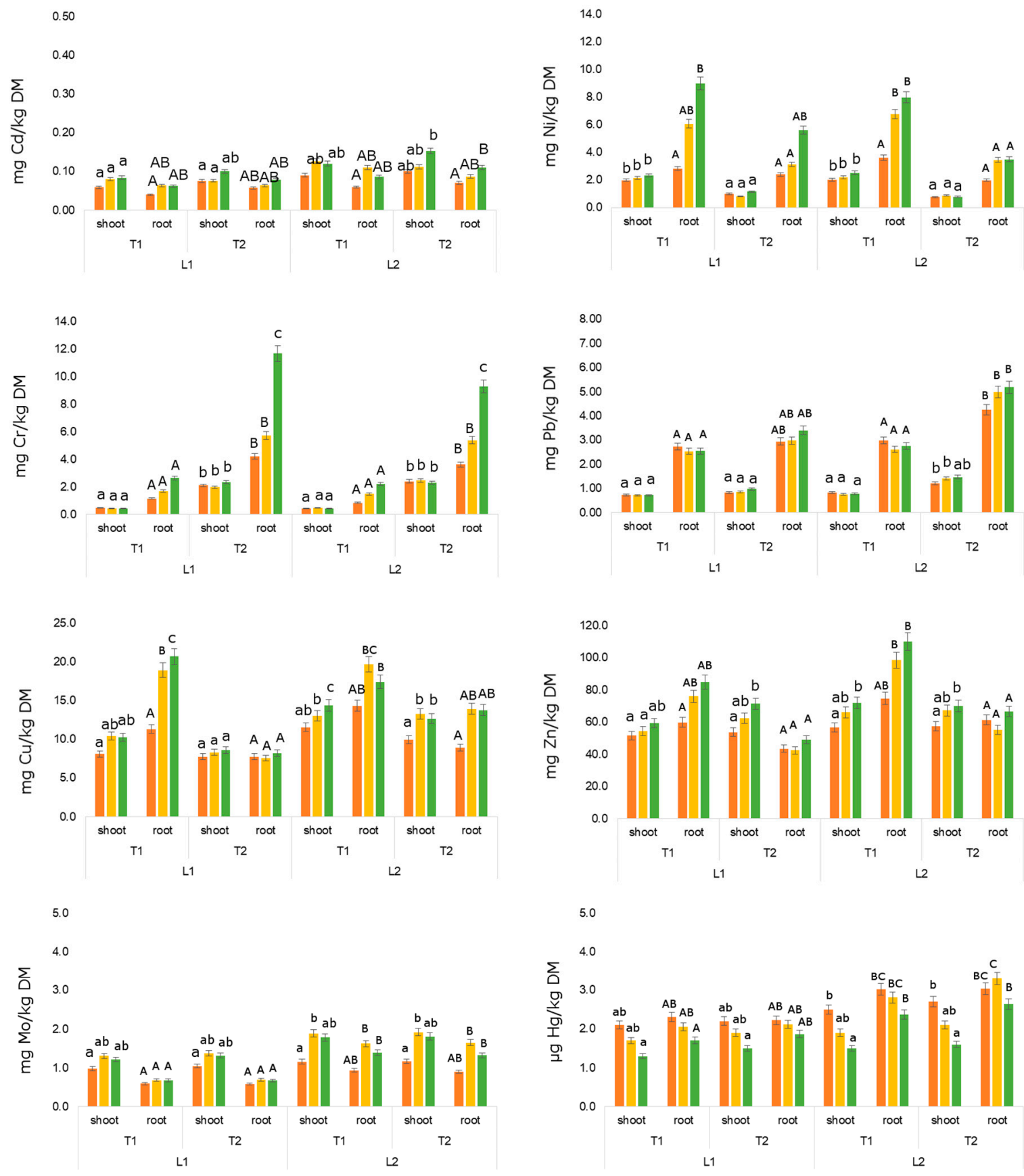

$\square \mathrm{C} \backsim \mathrm{G} 1 \backsim \mathrm{G} 2$

Figure 5. The average content of $\mathrm{HMs}(\mathrm{Cd}, \mathrm{Cr}, \mathrm{Cu}, \mathrm{Mo}, \mathrm{Ni}, \mathrm{Pb}, \mathrm{Zn}$, and $\mathrm{Hg})$ in shoot and root of grass mixture samples from the control plots (C) and plots fertilized with sewage sludge in a dose of 14.5 t DM/ha (G1) and 29 t DM/ha (G2) in L1 and L2, collected in first (T1) and second (T2) year of study. Different letters (small letters—shoot, capital letters—root) above bars (mean $\pm \mathrm{SD}$ ) represented significant differences assessed with the Tukey test at $p<0.05$.

\subsection{Bioconcentration (BCF) and Translocation (TF) Factors and Their Relationship with Soil Properties}

Figure 6 presents the results of the mean of $\mathrm{BCF}$ and TF calculated for $\mathrm{Cd}, \mathrm{Cr}, \mathrm{Cu}, \mathrm{Mo}$, $\mathrm{Ni}, \mathrm{Pb}, \mathrm{Zn}$, and $\mathrm{Hg}$. The obtained test results indicate that the factors depended on the analyzed metal, sediment dose, sampling date, and location. The lowest values of BCF were obtained for $\mathrm{Ni}, \mathrm{Cr}$, and $\mathrm{Pb}$ and they ranged from 0.02 to 0.50 , while the highest for $\mathrm{Mo}, \mathrm{Cd}, \mathrm{Cu}$, and $\mathrm{Zn}$ (from 0.25 to 1.97). BCF coefficients greater than 1 were recorded for 
Mo (all treatments), Cd (G2), $\mathrm{Cu}$ (T2), and Zn (T2, L1). As demonstrated in the presented results, the $\mathrm{BCF}$ calculated for all metals except $\mathrm{Pb}$ differed significantly depending on the year of the study. In the case of $\mathrm{Cd}, \mathrm{Ni}$ in $\mathrm{T} 2$ there was a decrease in this parameter, and an increase for $\mathrm{Mo}, \mathrm{Cr}, \mathrm{Cu}$, and $\mathrm{Zn}$. The effect of the sludge application and its dose on the BCF coefficient was observed for $\mathrm{Cd}(\mathrm{T} 1, \mathrm{~L} 1), \mathrm{Cu}$, and $\mathrm{Zn}$, but the obtained effect was not statistically significant. The TF factors were the lowest values for $\mathrm{Cr}, \mathrm{Ni}$, and $\mathrm{Pb}$ when the highest for $\mathrm{Mo}, \mathrm{Cd}, \mathrm{Cu}$, and $\mathrm{Zn}$. Statistical analysis indicated that sewage sludge influenced on the migration of $\mathrm{Ni}$ from roots to shoots.
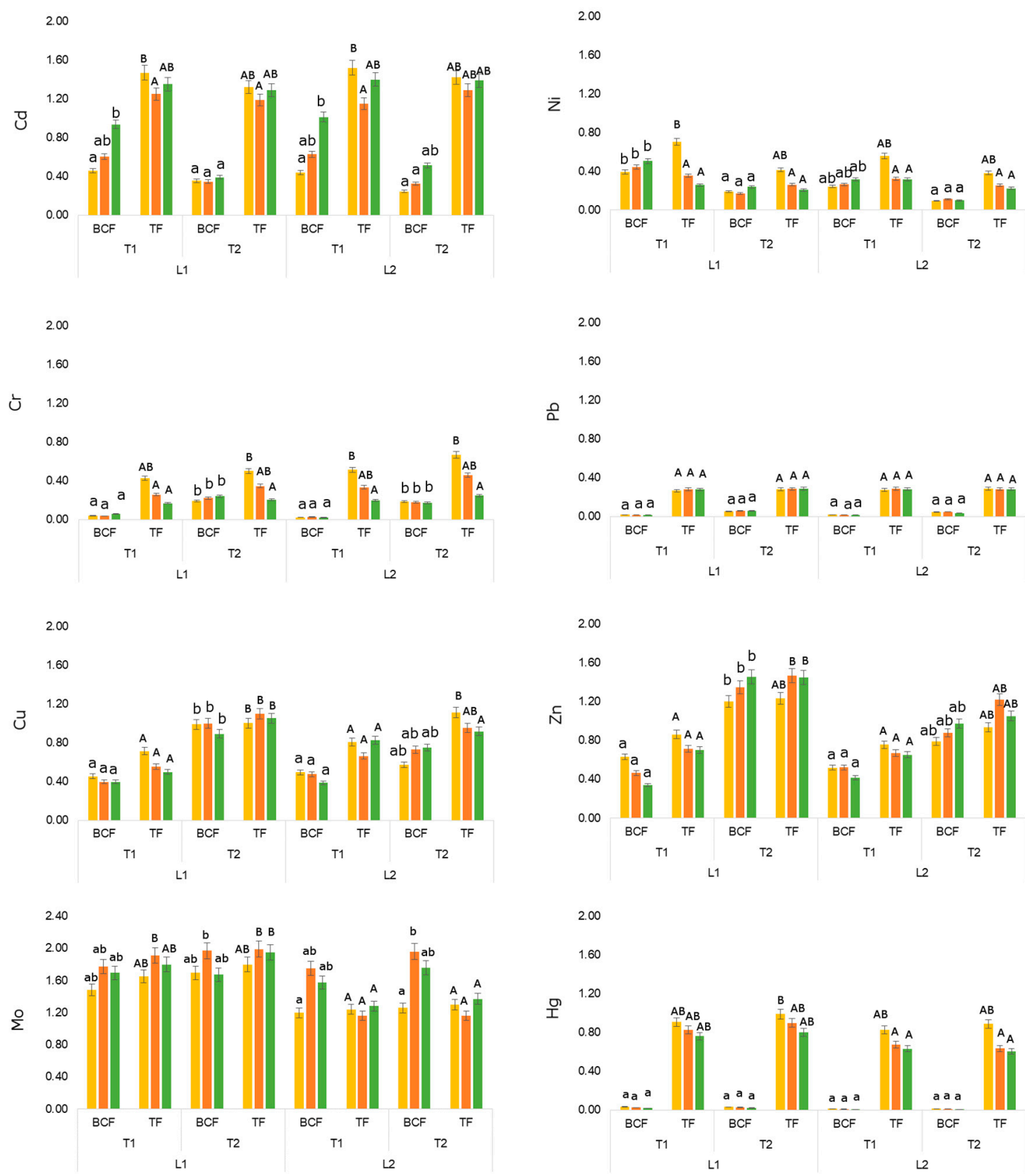

$$
\llbracket \mathrm{C} \backsim \mathrm{G} 1 \backsim \mathrm{G} 2
$$

Figure 6. Bioconcentration (BCF) and translocation (TF) factors calculated for $\mathrm{Cd}, \mathrm{Cr}, \mathrm{Cu}, \mathrm{Mo}, \mathrm{Ni}, \mathrm{Pb}, \mathrm{Zn}$, and $\mathrm{Hg}$ for soil and grass mixture samples from the control plots (C) and plots fertilized with sewage sludge in a dose of 14.5 t DM/ha (G1) and 29 t DM/ha (G2) in L1 and L2, collected in first (T1) and second (T2) year of study. Different letters (small letters-shoot, capital letter-root) above bars (mean $\pm \mathrm{SD}$ ) represented significant differences assessed with the Tukey test at $p<0.05$. 
Pearson's correlation analysis showed that positive significant correlations occurred between the bioconcentration factor calculated for $\mathrm{Zn}, \mathrm{Cd}, \mathrm{Ni}$, and DHA activity in the soil, and between CAT activity and BCF calculated for $\mathrm{Cd}, \mathrm{Cu}$, and $\mathrm{Zn}$ (Table 3). Moreover, a positive correlation was found between soil $\mathrm{pH}$ and $\mathrm{OM}$ content and $\mathrm{BCF}(\mathrm{Zn}), \mathrm{BCF}(\mathrm{Mo})$. Negative significant correlations were found for the BCF calculated for most tested metals and their presence in the soil in the F4 fraction. Moreover, negative significant relationships were demonstrated for the $\mathrm{BCF}$ coefficient calculated for $\mathrm{Cd}$ and $\mathrm{Ni}$ and their presence in the F2 fraction. Significant positive correlations were found for the presence of $\mathrm{Cd}, \mathrm{Cu}$, and $\mathrm{Zn}$ in the $\mathrm{F} 1$ fraction and $\mathrm{BCF}$ calculated for $\mathrm{Cd}, \mathrm{Cu}$, and $\mathrm{Zn}$. Different relationships were found for the TF. Significant positive correlations were noted between soil enzyme activity (DHA, CAT) and TF calculated for $\mathrm{Ni}, \mathrm{Pb}$, and $\mathrm{Zn}$. The significant correlations were also between $\operatorname{TF}(\mathrm{Zn})$ and $\mathrm{TF}(\mathrm{Cu})$ and their bounding in the $\mathrm{F} 1$ and $\mathrm{F} 3$ fractions $(\mathrm{Zn})$. However, significant negative correlations between $\mathrm{OM}$ and TF evaluated for $\mathrm{Cr}$ and $\mathrm{Ni}$ were observed.

Table 3. This the Pearson's correlation coefficients $(r, p<0.05)$ for BCF and TF of analyzed HMs and selected soil properties.

\begin{tabular}{|c|c|c|c|c|c|c|c|c|c|}
\hline HMs & $\mathrm{pH}$ & OM & clay & DHA & CAT & F1 & F2 & F3 & F4 \\
\hline \multicolumn{10}{|c|}{$\mathrm{BCF}$} \\
\hline $\mathrm{Cd}$ & -0.5 & 0.6 & ns & 0.6 & 0.5 & 0.7 & -0.5 & 0.4 & -0.4 \\
\hline $\mathrm{Cr}$ & -0.4 & ns & ns & ns & ns & ns & ns & ns & -0.6 \\
\hline $\mathrm{Cu}$ & -0.5 & ns & ns & ns & 0.6 & 0.7 & 0.5 & -0.8 & -0.8 \\
\hline Mo & 0.6 & 0.5 & ns & ns & ns & ns & ns & 0.5 & ns \\
\hline $\mathrm{Ni}$ & ns & ns & ns & 0.5 & ns & ns & -0.8 & 0.3 & -0.6 \\
\hline $\mathrm{Pb}$ & ns & ns & ns & ns & ns & ns & 0.5 & ns & -0.6 \\
\hline $\mathrm{Zn}$ & 0.6 & 0.5 & ns & 0.6 & 0.5 & 0.8 & ns & 0.7 & -0.4 \\
\hline $\mathrm{Hg}$ & ns & 0.4 & ns & ns & ns & ns & ns & ns & ns \\
\hline \multicolumn{10}{|c|}{$\mathrm{TF}$} \\
\hline $\mathrm{Cd}$ & ns & ns & ns & ns & ns & ns & ns & ns & ns \\
\hline $\mathrm{Cr}$ & ns & -0.6 & ns & ns & ns & ns & ns & 0.4 & ns \\
\hline $\mathrm{Cu}$ & ns & ns & ns & ns & ns & 0.6 & ns & ns & ns \\
\hline Mo & ns & ns & ns & ns & ns & ns & ns & ns & ns \\
\hline $\mathrm{Ni}$ & ns & -0.7 & ns & ns & 0.4 & ns & ns & ns & ns \\
\hline $\mathrm{Pb}$ & ns & ns & ns & 0.4 & 0.6 & ns & ns & ns & ns \\
\hline $\mathrm{Zn}$ & ns & ns & ns & 0.5 & ns & 0.4 & 0.5 & 0.7 & ns \\
\hline $\mathrm{Hg}$ & ns & ns & ns & ns & ns & ns & ns & ns & ns \\
\hline
\end{tabular}

Explanations: HM-heavy metal, BCF-bioconcentration factor, TF-translocation factor, OM—organic matter, DHA-soil dehydrogenases activity, CAT—soil catalase activity, F1, F2, F3, F4—respectively acid-soluble, reducible, oxidizable, and residual fractions of tested heavy metals, ns-non-significant differences.

\section{Discussion}

\subsection{Sewage Sludge Effect on Heavy Metals Content in Soil}

An increased concentration of HMs in the environment is a global problem. It is related to their toxicity, high persistence in the environment, and ability to bioaccumulate. Moreover, the excessive level of HMs in soils in urban areas may pose a threat to urban residents' health due to their easy migration with dust particles into the respiratory tract and on the skin surface [1,21]. According to the present study, the addition of sewage sludge to urban soil did not cause any significant changes in HMs content. Wołejko et al. [18] state that the geochemical background of soil in northeastern Poland is for Cd, $<0.05 \mathrm{ppm} ; \mathrm{Cr}$, 5-10 ppm; Cu, 20-40 ppm; Ni, <5 ppm; Pb, 12.5-100 ppm; Zn, <400 ppm; and for Hg, $<0.8 \mathrm{ppm}$. In our study, higher $\mathrm{Cr}$ and $\mathrm{Ni}$ contents were found in T1 and T2. Comparing the obtained results with maximum permissible limits of tested HMs in the soil where sewage sludge is used to light soil according to National Regulation (Table S1), it was found that $\mathrm{Zn}$ content was exceeded in the soil in T1 from L1 and L2. However, comparing obtained results with the Directive 86/278/EEC [32], no exceedances of the examined HMs were found. An increase in $\mathrm{Zn}$ content in the soil in an urban area could be caused by 
the persistent exposition of soils to communication transport, which was described by Padmavathiamma and Li [33].

The conducted experiments allowed us to determine the following descending series: $\mathrm{Zn}>\mathrm{Pb}>\mathrm{Cu}>\mathrm{Cr}>\mathrm{Ni}>\mathrm{Mo}>\mathrm{Cd}>\mathrm{Hg}$ of the average HMs content in T1 and T2. As it was suggested by Shrivastava and Banerjee [10], the series representing HMs content in soil with sewage sludge depended on the location of the soils, and as in our study, Cd exhibited the lowest content in soils, followed by $\mathrm{Pb}$. Eid et al. [23] conducted a pot experiment in which, after the application of sewage sludge $(50 \mathrm{~g} / \mathrm{kg}$ dose) to the soil, the descending series of metal contents were determined as $\mathrm{Zn}>\mathrm{Cr}>\mathrm{Ni}>\mathrm{Cu}>\mathrm{Pb}>\mathrm{Cd}$. In the present study, a higher content of $\mathrm{Pb}$ in comparison with other metals is related to the location of the research objects. In urban soil along transportation routes, the source of $\mathrm{Pb}$ is $\mathrm{Pb}$-containing dust from the combustion of gasoline with lead tetraethyl [34].

Xia et al. [35] reported that the content of HMs in urbanized areas depends on traffic intensity. In our study, different contents of some HMs in soil were obtained from the sites located at L1 and L2. Transport was the main source of metal contamination of soils in urban areas $(\mathrm{Cd}, \mathrm{Cr}$, and $\mathrm{Zn})$. The plots in the studied localization were characterized by different traffic intensities. According to Padmavathiamma and Li [33], the sources of $\mathrm{Cu}$ and $\mathrm{Zn}$ in the environment along traffic routes can be exhaust emissions, tires $(\mathrm{Zn})$, engine, and brake pad wear $(\mathrm{Cu})$. In addition, our study indicated that higher $\mathrm{Cu}$ contents in soil were recorded at location L2, where traffic volume was higher than at L1. In addition, the penetration of pollutants may also be influenced by the planting of other plants (e.g., trees and shrubs) that were present at L2.

The availability of HMs for plants depends on the form of their occurrence in soil. Determination of metal content in fractions allows for concluding about the possibility of migration of metals in soil-plant and soil-groundwater systems. A sequential analysis of the investigated HMs revealed differences in their occurrence in individual fractions, which depended on the year of study and, to a lesser extent, on the location of the plots and sewage sludge dose. The majority of the studied HMs were bound in a form of an unavailable fraction (F4), and in some cases, they were bound with organic matter (F3) fraction. The exception was $\mathrm{Zn}$, whose contribution to the easily available fraction (F1) was up to $40 \%$ of the total content in T1. In addition, metals such as $\mathrm{Cd}, \mathrm{Cu}$, and $\mathrm{Pb}$ showed high proportions in the potentially bioavailable F2 fraction. It was also conducted that increasing sludge dosage probably caused an increase in the proportion of $\mathrm{Mo}, \mathrm{Zn}$, and Ni in the F3 fraction. Gadepalle et al. [36] studied the effect of compost produced from sewage sludge and green waste on Cd fraction content and its uptake by Lolium perenne. The authors observed that $\mathrm{Cd}$ was mainly bound in the organic fraction and with increasing compost dose, the proportion of Cd in F2 and F1 fractions increased. Similar results were obtained in our study in which the highest amount of $\mathrm{Cd}$ in soil was bound in the F2 fraction. In $\mathrm{T} 1$, its proportion increased slightly with the applied sediment dose. The results obtained in our study regarding $\mathrm{Cr}$ were similar to the results obtained by Legret [37] after the application of a sludge dose of $10 \mathrm{t} / \mathrm{ha}$ /year, in which the series of $\mathrm{Cr}$ contribution to individual fractions in soils was as follows: residual fraction > oxidizable fraction $>$ reducible fraction $>$ carbonate fraction $>$ exchangeable fraction. On the basis of obtained results, we conclude that, in $\mathrm{T} 2$, the share of $\mathrm{Cr}$ in the fractions formed the following series: residual fraction $>$ oxidizable fraction $>$ reducible fraction $>$ acid-soluble fraction.

According to Kabata-Pendias [38], in areas with a low level of industrialization, the total $\mathrm{Cu}$ content ranged from $1 \mathrm{ppm}$ to $100 \mathrm{ppm}$, which is in accordance with our results. Moreover, $\mathrm{Cu}$ may occur also in the fraction with iron and manganese oxides and in the residual fraction [39]. Similar results were obtained in our research in T2. It was found that mostly $\mathrm{Cu}$ was bound in F2 and F4 fractions. The addition of sewage sludge to soils may cause $\mathrm{Cu}$ binding in the oxidizable fraction (bound to organic matter). This is confirmed by the results obtained in $\mathrm{T} 1$ and $\mathrm{T} 2$.

$\mathrm{Zn}$ is another metal important in the area of plant nutrition. In unpolluted soil in Poland, its content was about 40 ppm [38]. It is one of the elements whose above-normal 
contents are observed in soils in urban areas located in close proximity to communication routes. Moreover, Zn belongs to the most mobile metals in soils. Wiater and Łukowski [40] studies on the quality of cultivated soil showed that a large part of $\mathrm{Zn}$ in soils was bound in the fraction with iron and manganese oxides, while the least $\mathrm{Zn}$ was in the residual fraction. It was also observed that with increasing organic matter in soils, the proportion of $\mathrm{Zn}$ content in the F3 fraction increased. A similar relation was obtained in our study. The application of increasing doses of sewage sludge to soils resulted in an increase in the proportion of $\mathrm{Zn}$ in the F3 fraction.

\subsection{Sewage Sludge Effect on Plant Yield and Its Ability to Promote HMs Accumulation}

As it was reported by Zhao et al. [41], the productivity of lawns is an important measurement used for assessing the functioning of natural areas in urban zones, where there should be a balance between the amount of biomass produced and the ability to capture pollutants from the air, neutralize toxic substances from the soil, produce oxygen and fix carbon dioxide, or increase air humidity and perform an aesthetic function. Moreover, the amount of produced plant biomass determines the fertility of soils. In our study, in $\mathrm{T} 1$ the average total yield for the control was $2.56 \mathrm{t} \mathrm{DM} /$ ha. The addition of sewage sludge to the soil at the rate of $14.5 \mathrm{t} \mathrm{DM} /$ ha and $29 \mathrm{tDM} /$ ha resulted in an increase in yield to $4.26 \mathrm{t} \mathrm{DM} /$ ha and $4.91 \mathrm{t} \mathrm{DM} /$ ha, respectively. In T2, the obtained yield was similar. The grass yields obtained were higher than in experiments conducted by other authors. Smith and Tibbett [42] conducted a pot study in which they added sewage sludge at three doses ( $4 \mathrm{t} / \mathrm{ha}, 8 \mathrm{t} / \mathrm{ha}$, and $16 \mathrm{t} / \mathrm{ha}$ ) to sandy loam soils on which Lolium perenne was sown. Two harvestings (after 35 days and 70 days after sowing) from the soil treated with sludge gave the total yield for doses of $4 \mathrm{t} / \mathrm{ha}, 8 \mathrm{t} / \mathrm{ha}$, and $16 \mathrm{t} / \mathrm{ha}$, respectively, $1.68 \mathrm{t} \mathrm{DM} / \mathrm{ha}$, $2.04 \mathrm{t} \mathrm{DM} / \mathrm{ha}$, and $2.46 \mathrm{t} \mathrm{DM} / \mathrm{ha}$, and for the control, $1.27 \mathrm{t} \mathrm{DM} / \mathrm{ha}$. In this case, the yield was lower than that obtained in our study.

The uptake of HMs by plants depends on soil properties, sewage sludge origin and its properties and dose, plant species, plant physiology, and chemical forms of metals [23]. In the present study, the content of HMs and their accumulation in grass mixtures depended mainly on the metal and the year of study, and to a lesser extent, on the location and dose of sludge. In T1, at the plots fertilized with sludge the average BCF of individual HMs in the above-ground parts of lawn grasses mixture was as follows: $\mathrm{Mo}>\mathrm{Cd}>\mathrm{Cu}>\mathrm{Zn}$ $>\mathrm{Ni}>\mathrm{Cr}>\mathrm{Pb}>\mathrm{Hg}$. In T2, the descending series of mean BCF values in the soil with sediments were as follows: $\mathrm{Mo}>\mathrm{Zn}>\mathrm{Cu}>\mathrm{Cd}>\mathrm{Cr}>\mathrm{Ni}>\mathrm{Pb}>\mathrm{Hg}$. On the basis of the conducted research, it can be concluded that the grass mixture used showed potential for extraction of $\mathrm{Zn}, \mathrm{Cu}$, and $\mathrm{Cd}$, which was evidenced by BCF $>1.0$ and $\mathrm{TF}>1$ values obtained in T1 (Cd) and T2 ( $\mathrm{nn}$ and $\mathrm{Cu}$ ). Higher bioconcentration of $\mathrm{Zn}$ in the mixture of lawn grasses may be related to the high proportion of $\mathrm{Zn}$ in the soil occurring in the easily available fraction (F1), which is confirmed by the positive significant correlation coefficient $(\mathrm{r}=0.8)$. It may be supposed that high uptake of $\mathrm{Cd}$ and $\mathrm{Cu}$ by grass mixtures is connected with their combination in the F2 fraction $(\mathrm{Cu}$ and $\mathrm{Cd})$ and $\mathrm{F} 3$ fraction $(\mathrm{Cu})$, which under suitable conditions are potentially available to plants. Under the influence of organic matter inputs such as sewage sludge, $\mathrm{Cd}$ may form soluble and mobile chelates with organic matter in the soil. In the presence of phosphorus, of which bio-waste may also be a source, it may convert to oxide-bound forms ( $\mathrm{Fe}, \mathrm{Mn}$ ) and, to a small extent, to organic forms. However, higher bioavailability of $\mathrm{Cu}$ for plants may also be related to the occurrence of this metal in combinations with low molecular weight organic matter, released during the decomposition of organic matter (including bio-waste), the presence of which increases $\mathrm{Cu}$ mobility. Additionally, the behavior of $\mathrm{Cu}$ is influenced by Fe and $\mathrm{Mn}$ hydroxides and interactions with other elements [34]. This is also reflected in the significant correlation of $\mathrm{BCF}(\mathrm{Cd})$ and $\mathrm{BCF}(\mathrm{Cu})$ with their soil content in $\mathrm{F} 3$ and $\mathrm{F} 2$ fractions.

The extraction of metals by plants and their BCF is also affected by the soil pH. Statistical analysis showed significant negative correlations between the soil $\mathrm{pH}$ and $\mathrm{BCF}$ calculated for $\mathrm{Cu}$ and positive correlation for $\mathrm{pH}$ and $\mathrm{BCF}$ conducted for $\mathrm{Zn}$ and Mo. 
Therefore, it can be assumed that in alkaline soils, including urban soils, the mobility and bioavailability of Zn may increase after the sewage sludge application, while the uptake of $\mathrm{Cu}$ by plants may be hindered. According to Kabata-Pendias [38], in alkaline soil, Zn can form complex anions and organic-mineral combinations, which are characterized by high mobility. Mo is an essential microelement important for plant and animal nutrition. According to Kabata-Pendias [38], its solubility in soil depends on the $\mathrm{pH}$ and increases with its increase. This statement is in agreement with those resulting from our study. The obtained results show that BCF of Cd and Mo was positively correlated with the content of organic matter in soil and with the occurrence of $\mathrm{Cd}$ and Mo in the F3 fraction. In general, $\mathrm{Cd}$ shows mobility and phytoavailability in soils regardless of the $\mathrm{pH}$ and is as easily taken up by the root system as by the shoots. It may also increase when organic matter is added to the soil. In the case of Mo, in soils enriched with organic matter, Mo can bind to organic polymers, from where it is released gradually [38].

According to Yoon et al. [43], elevated soil $\mathrm{pH}$ and high content of organic matter in it, as a result of adding organic substrates, including sewage sludge, may limit the availability of metals in soils for plants, and thus lead to immobilization of HMs in the soil by forming insoluble complexes with organic matter. Due to the adsorption processes that take place on the surface of organic molecules, the organic substance reduces the transfer of pollutants to groundwater [44]. In our study, the $\mathrm{pH}$ of the soil on which the experiment was carried was alkaline; therefore, adding organic matter in the form of sludge could cause immobilization of HMs in the root system. Additionally, plants from the Poaceae and Fabaceae families (species, e.g., Lollium perenne, Festuca rubra, Poa pratensis, and Agrostis capillaris) have the ability to bound HMs in the root system $[45,46]$. In the current study, the experiments were set up with the use of lawn grass mixtures containing Lollium perenne, Festuca rubra, and Poa pratensis, which were characterized by a suitable potential for HMs phytostabilization. The potential ability of plants to metals immobilization in roots and in soil may also be influenced by the BCF/TF factors, calculated for the content of a given metal in the aboveground parts of plants to the content of this metal in the soil/root, assuming a value below 1.0. The lowest BCF and TF were obtained for $\mathrm{Pb}$ and $\mathrm{Cr}$. Moreover, $\mathrm{BCF}<1.0$ occurred for the most of tested metals (except for Cd from G2 plots), while in the second year for $\mathrm{Cd}, \mathrm{Cr}, \mathrm{Ni}$, and $\mathrm{Pb}$. Furthermore, low $\mathrm{TF}$ we obtained for $\mathrm{Cr}, \mathrm{Ni}$, and $\mathrm{Pb}$, which proves their limited migration from the roots to the above-ground part of grasses. According to Yoon et al. [43] and Kacprzak et al. [20], Pb is accumulated mainly in plant roots, which may be confirmed by the obtained results in which BCF and TF coefficients values were low. However, in the studies of Yang et al. [39] and Zhang et al. [47], Cu and Cd showed low BCF of the tested plants $(\mathrm{BCF}<1)$, and most often these metals were accumulated in the roots in greater amounts than in the above-ground parts. Low BCF and TF factors for $\mathrm{Cu}$ and $\mathrm{Cd}$ were obtained in T1 and T2, respectively. Cheraghi et al. [48] also obtained a low ratio of $\mathrm{Cu}$ content in plants of the Poacea to the total $\mathrm{Cu}$ content in the soil.

The uptake and accumulation of HMs by plants may also depend on the content of organic substances in soil, soil $\mathrm{pH}$, soil particle composition, metal forms in soil, and soil biological activity [49]. Presented research showed both positive and negative significant correlations for the BCF and TF with the tested soil characteristics depending on the location and year of the study, which may indicate a complex and ambiguous influence of the application of sludge to urban soils. The obtained results were different depending on the year of the experiment, which confirmed the observations of Padmavathiamma and $\mathrm{Li}$ [46], indicating that the uptake of metals by plants shows seasonal changes.

\section{Conclusions}

Urban soils are continuously exposed to chemical, physical, and mechanical degradation, the main sources of which are the developing industry and transport. Treatments involving the fertilization of urban soils with sewage sludge with a low heavy metal content will increase the green biomass produced by the soil, capable of producing oxygen, absorbing a range of harmful substances contained in the air, reducing the migration of pollutants 
to groundwater, and increasing aesthetic and health values. In addition, the use of sewage sludge in order to improve the growth conditions of grasses is an interesting alternative use of this bio-waste. As indicated by the presented results, the ability of the applied grass mixtures to uptake heavy metals from unpolluted soils after sewage sludge application is not high, due to the low biomass production of the grasses, and only concerns some metals. The application of sewage sludge to high $\mathrm{pH}$ urban soils may cause immobilization of HMs in the soil with selected varieties of lawn grasses. This process is also supported by the fact that during the experiment, most HMs in soils occurred in the residual fraction or in potentially available fractions (reducible and oxidizable fractions). Only Zn showed a high proportion in the easily accessible fraction. The occurrence of metals in the available and potentially available fractions determined the higher BCF and TF values.

The paper proposes a concept for solving the problem of sludge utilization that is innovative because it is based on multifaceted research on street lawns fertilized with different doses of stabilized sewage sludge under real conditions and refers to the occurrence of multiple pollutants simultaneously. It should be emphasized that research conducted in field conditions over a longer period of time allows for obtaining reliable results, which reflects the natural conditions of the area during the experiment. However, the disadvantage of such studies under uncontrolled conditions is the impossibility of unequivocally determining the influence of all factors that may determine uptake or immobilization of metals by plants. It makes it difficult to identify the factors that guarantee successful phytoremediation. Further research should concern the chemical and biological analyses of the root system of plants living in urban soil fertilized with sewage sludge. In particular, they should include the study of biodiversity and the influence of microorganisms inhabiting the soil environment of urban areas on the efficiency of the phytoremediation process of sludge-fertilized soil.

Supplementary Materials: The following are available online at https:/ / www.mdpi.com/1996-107 3/14/6/1584/s1, Table S1: The maximum permissible values for HMs concentrations (mg/kg DM) according to the Regulation of the Minister of the Environment of 6 February 2015 on municipal sewage sludge (Poland) [21] and Directive 86/278/EEC [28].

Author Contributions: Conceptualization, U.W. and E.W.; methodology, U.W. and E.W.; investigation, U.W., E.W., E.H., J.R. and W.J.; writing—original draft preparation, U.W.; writing-review and editing, A.J.-T.; visualization, U.W., E.W. and A.J.-T.; funding acquisition, A.B. All authors have read and agreed to the published version of the manuscript.

Funding: This work was financially supported by the Ministry of Science and Higher Education, Poland, under the research project number WZ/WB-IIŚ/3/2019.

Institutional Review Board Statement: Not applicable.

Informed Consent Statement: Not applicable.

Data Availability Statement: Not applicable.

Conflicts of Interest: The authors declare no conflict of interest.

\section{References}

1. Foti, L.; Dubs, F.; Gignoux, J.; Lata, J.-C.; Lerch, T.Z.; Mathieu, J.; Nold, F.; Nunan, N.; Raynaud, X.; Abbadie, L.; et al. Trace element concentrations along a gradient of urban pressure in forest and lawn soils of the Paris region (France). Sci. Total Environ. 2017, 598, 938-948. [CrossRef]

2. Luo, X.; Yu, S.; Zhu, Y.; Li, X. Trace metal contamination in urban soils of China. Sci. Total Environ. 2012, 421-422, 17-30. [CrossRef]

3. Yang, J.-L.; Zhang, G.-L. Formation, characteristics and eco-environmental implications of urban soils-A review. Soil Sci. Plant Nutr. 2015, 61 (Suppl. 1), 30-46. [CrossRef]

4. Chen, X.; Guo, M.; Feng, J.; Liang, S.; Han, D.; Cheng, J. Characterization and risk assessment of heavy metals in road dust from a developing city with good air quality and from Shanghai, China. Environ. Sci. Pollut. Res. 2019, 26, 11387-11398. [CrossRef] [PubMed]

5. Hong, N.; Guan, Y.; Yang, B.; Zhong, J.; Zhu, P.; Ok, Y.S.; Hou, D.; Tsang, D.C.W.; Guan, Y.; Liu, A. Quantitative source tracking of heavy metals contained in urban road deposited sediments. J. Hazard. Mater. 2020, 393, 122362. [CrossRef] [PubMed] 
6. Hanfi, M.Y.; Mostafa, M.Y.A.; Zhukovsky, M.V. Heavy metal contamination in urban surface sediments: Sources, distribution, contamination control and remediation. Environ. Monit. Assess. 2019, 192, 32. [CrossRef] [PubMed]

7. Li, J.; He, M.; Han, W.; Gu, Y. Availability and mobility of heavy metal fractions related to the characteristics of the coastal soils developed from alluvial deposits. Environ. Monit. Assess. 2009, 158, 459-469. [CrossRef]

8. Anjos, C.; Magalhães, M.C.M.; Abreu, M.M. Metal (Al, Mn, Pb and $\mathrm{Zn}$ ) soils extractable reagents for available fraction assessment: Comparison using plants, and dry and moist soils from the Braçal abandoned lead mine area, Portugal. J. Geochem. Explor. 2011, 113, 45-55. [CrossRef]

9. Niesiobędzka, K. Transfer of copper, lead and zinc in soil-grass ecosystem in aspect of soil properties, in Poland. Bull. Environ. Contam. Toxicol. 2012, 88, 627-633. [CrossRef]

10. Shrivastava, S.K.; Banerjee, D.K. Speciation of metals in sewage sludge and sludge-amended soils. Water Air Soil Pollut. 2004, 152, 219-232. [CrossRef]

11. Rao, C.R.M.; Ashuquillo, A.; Lopez Sanchez, J.F. Review of the different methods applied in environmental geochemistry for single and sequential extraction of trace elements in soils and related materials. Water Air Soil Pollut. 2008, 189, 291-333. [CrossRef]

12. Bogusz, A.; Oleszczuk, P. Sequential extraction of nickel and zinc in sewage sludge- or biochar/sewage sludge-amended soil. Sci. Total Environ. 2018, 636, 927-935. [CrossRef] [PubMed]

13. Park, M.; Yoon, H.; Yoon, C.; Yu, J.-Y. Estimation of mercury speciation in soil standard reference materials with different extraction methods by ion chromatography coupled with ICP-MS. Environ. Geochem. Health 2010, 33, 49-56. [CrossRef] [PubMed]

14. Zemberyova, M.; Hagarova, I.; Zimova, J.; Bartekova, J.; Kuss, H.M. Determination of molybdenum in extracts of soil and sewage sludge CRMs after fractionation by means of BCR modifie sequential extraction procedure. Talanta 2010, 82, 582-586. [CrossRef]

15. Yuan, C.; Shi, J.; He, B.; Liu, J.; Liang, L.; Jiang, G. Speciation of heavy metals in marine sediments from the East China Sea by ICP-MS with sequential extraction. Environ. Int. 2004, 30, 769-783. [CrossRef]

16. Agilent Technologies, Inc. Collision/Reaction Cells in ICP-MS. 2010. Available online: https://www.agilent.com/cs/library/ articlereprints/Public/5990_5955EN\%20HR.pdf (accessed on 16 February 2021).

17. Franzetti, A.; Gandolfi, I.; Bestetti, G.; Schioppa, E.P.; Canedoli, C.; Brambilla, D.; Cappelletti, D.; Sebastiani, B.; Federici, E.; Papacchini, M.; et al. Plant-microorganisms interaction promotes removal of air pollutants in Milan (Italy) urban area. J. Hazard. Mater. 2020, 384, 121021. [CrossRef] [PubMed]

18. Wołejko, E.; Wydro, U.; Butarewicz, A.; Łoboda, T. Effects Of Sewage Sludge On The Accumulation Of Heavy Metals In Soil And In Mixtures Of Lawn Grasses. Environ. Prot. Eng. 2013, 39, 67-76. [CrossRef]

19. Jabeen, R.; Ahmad, A.; Iqbal, M. Phytoremediation of Heavy Metals: Physiological and Molecular Mechanisms. Bot. Rev. 2009, 75, 339-364. [CrossRef]

20. Kacprzak, M.; Grobelak, A.; Grosser, A.; Prasad, M.N.V. Efficacy of biosolids in assisted phytostabilization of metalliferous acidic sandy soils with five grass species. Int. J. Phytoremediation. 2014, 16, 593-608. [CrossRef]

21. Wu, D.; Yu, X.; Lai, M.; Feng, J.; Dong, X.; Peng, W.; Su, S.; Zhang, X.; Wan, L.; Jacobs, D.F.; et al. Diversified effects of co-planting landscape plants on heavy metals pollution remediation in urban soil amended with sewage sludge. J. Hazard. Mater. 2021, 403, 123855. [CrossRef]

22. Dede, G.; Ozdemir, S.; Dede, O.H. Effect of soil amendments on phytoextraction potential of Brassica juncea growing on sewage sludge. Int. J. Environ. Sci. Technol. 2012, 9, 559-564. [CrossRef]

23. Frąc, M.; Jezierska-Tys, S.; Oszust, K.; Gryta, A.; Pastor, M. Assessment of microbiological and biochemical properties of dairy sewage sludge. Int. J. Environ. Sci. Technol. 2017, 14, 679-688. [CrossRef]

24. Singh, R.P.; Agrawal, M. Potential benefits and risks of land application of sewage sludge. Waste Manag. 2008, 28, 347-358. [CrossRef]

25. The Regulation of the Minister of the Environment. Pol. J. Laws 2015, 257. Available online: http://isap.sejm.gov.pl/isap.nsf/ download.xsp/WDU20150000257/O/D20150257.pdf (accessed on 16 February 2021).

26. Imperato, M.; Adamo, P.; Naimo, D.; Arienzo, M.; Stanzione, D.; Violante, P. Spatial distribution of heavy metals in urban soils of Naples city (Italy). Environ. Pollut. 2003, 124, 247-256. [CrossRef]

27. Eid, E.M.; El-Bebany, A.F.; Taher, M.A.; Alrumman, S.A.; Hussain, A.A.; Galal, T.M.; Shaltout, K.H.; Sewelam, N.A.; Ahmed, M.T.; El-Shaboury, G.A. Influences of sewage sludge-amended soil on heavy metal accumulation, growth and yield of rocket plant (E. sativa). Appl. Ecol. Environ. Res. 2020, 18, 3027-3040. [CrossRef]

28. Casida, L.E., Jr.; Klein, D.A.; Santoro, T. Soil dehydrogenase activity. Soil Sci. 1964, 98, 371-376. [CrossRef]

29. Johnson, J.I.; Temple, K.L. Some variables affecting the measurements of catalase activity in soil. Soil Sci. Soc. Am. J. 1964, 28, 207-216. [CrossRef]

30. Rauret, G.; López-Sánchez, J.F.; Sahuquillo, A.; Rubio, R.; Davidson, C.; Ure, A.; Quevauviller, P. Improvement of the BCR three-step sequential extraction procedure prior to the certification of new sediment and soil reference materials. J. Environ. Monit. 1999, 1, 57-61. [CrossRef] [PubMed]

31. Leśniewska, B.; Krymska, M.; Świerad, E.; Wiater, J.; Godlewska-Żyłkiewicz, B. An ultrasound-assisted procedure for fast screening of mobile fractions of $\mathrm{Cd}, \mathrm{Pb}$ and $\mathrm{Ni}$ in soil. Insight into method optimization and validation. Environ. Sci. Pollut. Res. 2016, 2, 25093-25104. [CrossRef] 
32. Council of European Union. Council Directive 86/278/EEC of 12 June 1986 on the Protection of the Environment, and in Particular of the Soil, When Sewage Sludge is Used in Agriculture; Publications Office of the EU: Luxembourg, 1986; pp. 1-7.

33. Padmavathiamma, P.K.; Li, L.Y. Phytoremediation Technology: Hyper-accumulation metals in plants. Water Air Soil Pollut. 2007, 184, 105-126. [CrossRef]

34. Wei, B.; Yang, L. A review of heavy metal contaminations in urban soils, urban road dusts and agricultural soils from China. Microchem. J. 2010, 94, 99-107. [CrossRef]

35. Xia, X.; Chen, X.; Liu, R.; Liu, H. Heavy metals in urban soils with various types of land use in Beijing, China. J. Hazard. Mater. 2011, 186, 2043-2050. [CrossRef] [PubMed]

36. Gadepalle, V.P.; Ouki, S.K.; Hutchings, T. Remediation of copper and cadmium in contaminated soils using compost with inorganic amendments. Water Air Soil Pollut. 2009, 196, 355-368. [CrossRef]

37. Legret, M. Speciation of heavy metals in sewage sludge and sludge-amended soil. Int. J. Environ. Anal. Chem. 1993, 51, 161-165. [CrossRef]

38. Kabata-Pendias, A. Trace Elements in Soils and Plants; Taylor \& Francis: Abingdon, UK, 2010; p. 520.

39. Yang, H.F.; Wang, Y.B.; Huang, Y.J. Chemical fraction and phytoavailability of copper to rape grown in the polluted paddy soil. Int. J. Environ. Sci. Technol. 2015, 12, 2929-2938. [CrossRef]

40. Wiater, J.; Łukowski, A. Content of total zinc and its fractions in selected soils in the Province of Podlasie. J. Elem. 2014, 19, 811-820. [CrossRef]

41. Zhao, F.J.; Lombi, E.; McGrath, S.P. Assessing the potential for zinc and cadmium phytoremediation with the hyperaccumulator Thlaspi caerulescens. Plant Soil 2003, 249, 37-43. [CrossRef]

42. Smith, M.T.E.; Tibbett, M. Nitrogen dynamics under Lolium perenne after a single application of three different sewage sludge types from the same treatment stream. Bioresour. Technol. 2004, 91, 233-241. [CrossRef]

43. Yoon, J.; Cao, X.; Zhou, Q.; Ma, L.Q. Accumulation of $\mathrm{Pb}, \mathrm{Cu}$, and $\mathrm{Zn}$ in native plants growing on a contaminated Florida site. Sci. Total Environ. 2006, 368, 456-464. [CrossRef]

44. Zoghlami, R.I.; Hamadi, H.; Boudabbous, K.; Hechmi, S.; Khelil, M.N.; Jedidi, N. Seasonal toxicity variation in light-textured soil amended with urban sewage sludge: Interaction effect on cadmium, nickel, and phytotoxicity. Environ. Sci. Pollut. Res. 2017, 25, 3608-3615. [CrossRef]

45. Koptsik, G.N. Problems and prospects concerning the phytoremediation of heavy metal polluted soils: A review. Eurasian Soil Sci. 2014, 47, 923-939. [CrossRef]

46. Padmavathiamma, P.K.; Li, L.Y. Rhizosphere influence and seasonal impact on phytostabilisation of metals-A field study. Water Air Soil Pollut. 2012, 223, 107-124. [CrossRef]

47. Zhang, X.; Xia, H.; Li, Z.; Zhuang, P.; Gao, B. Potential of four forage grasses in remediation of Cd and Zn contaminated soils. Bioresour. Technol. 2010, 101, 2063-2066. [CrossRef]

48. Cheraghi, M.; Lorestani, B.; Khorasani, N.; Yousefi, N.; Karami, M. Findings on the Phytoextraction and Phytostabilization of Soils Contaminated with Heavy Metals. Biol. Trace Elem. Res. 2011, 144, 1133-1141. [CrossRef]

49. Mahdy, A.M.; Elkhatib, E.A.; Fathi, N.O. Cadmium, copper, nickel, and lead availability in biosolids-amended alkaline soils. Aust. J. Basic Appl. Sci. 2007, 1, 354-363. 